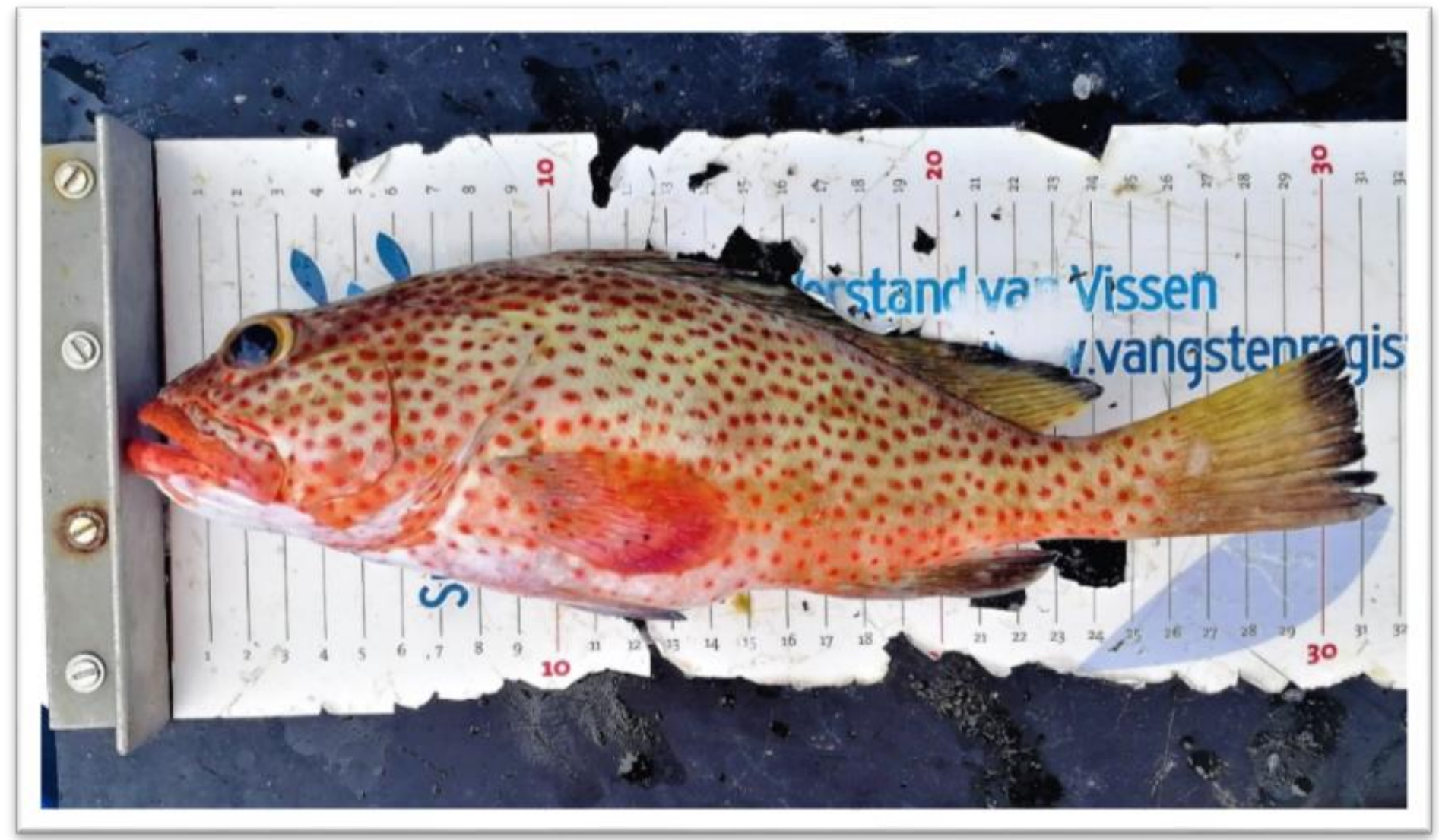

Assessing effectiveness of the seasonal closure of the Moonfish Bank of the Saba Bank for two species of concern, the Red Hind and the Queen Triggerfish: the first five years

Author(s): Adolphe O. Debrot, Thomas Brunel, Jessica Schop, 


\section{Assessing effectiveness of the seasonal closure of the Moonfish Bank of the Saba Bank for two species of concern, the Red Hind and the Queen Triggerfish: the first five years.}

Author(s): $\quad$ Adolphe O. Debrot ${ }^{1}$, Thomas Brunel ${ }^{1}$, Jessica Schop ${ }^{1}$, Ayumi Kuramae ${ }^{2}$, Yosha Bakkers ${ }^{2}$

1: Wageningen Marine Research

2: Saba Bank Management Unit

This research project was carried out by Wageningen Marine Research at the request of and with funding from the Ministry of Agriculture, Nature and Food Quality for the purposes of Policy Support Research Theme 'Caribisch Nederland' (project no. BO-43-021.04-002; Saba Bank Biodiversiteit). 
Keywords: seasonal closure, spawning aggregation, Red Hind, Epinephelus guttatus, Queen Triggerfish, Balistes vetula, Saba Bank.

Client: $\quad$ Ministry of Agriculture, Nature and Food Quality (LNV)

Attn.: Drs. Hayo Haanstra

Postbus 20401

2500 EK, Den Haag

BAS code (BO-43-021.04-002)

This report can be downloaded for free from https://doi.org/10.18174/520362

Wageningen Marine Research provides no printed copies of reports

Wageningen Marine Research is ISO 9001:2015 certified.

Photo cover: Yosha Bakkers

\section{(C) Wageningen Marine Research}

Wageningen Marine Research, an institute Wageningen Marine Research accepts no liability for consequential damage, nor within the legal entity Stichting for damage resulting from applications of the results of work or other data Wageningen Research (a foundation under obtained from Wageningen Marine Research. Client indemnifies Wageningen Dutch private law) represented by Dr. Marine Research from claims of third parties in connection with this application. M.C.Th. Scholten, Managing Director All rights reserved. No part of this publication may be reproduced and / or

KvK nr. 09098104, published, photocopied or used in any other way without the written permission WMR BTW nr. NL 8113.83.696.B16. Code BIC/SWIFT address: RABONL2U IBAN code: NL 73 RABO 0373599285 


\section{Contents}

$\begin{array}{lr}\text { Summary } & 4\end{array}$

$\begin{array}{llr}1 & \text { Introduction } & 6\end{array}$

2 Materials and Methods $\quad 9$

2.1 General approach $\quad 9$

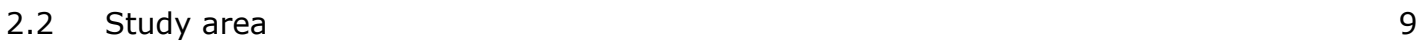

\begin{tabular}{ll}
2.3 & Distribution of fishing effort on the Bank \\
\hline
\end{tabular}

$\begin{array}{lll}2.4 & \text { Port sampling } & 11\end{array}$

2.5 Data preparation $\quad 11$

2.6 Analysis 12

$\begin{array}{lll}2.7 & \text { Fisheries independent population data } & 14\end{array}$

$3 \quad$ Results $r$

3.1 Red Hind 16

3.1.1 GLM analysis for the LP landings $\quad 16$

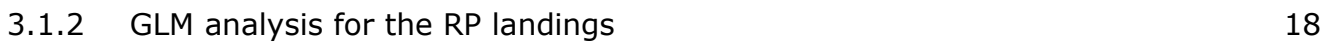

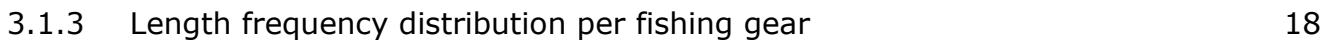

3.1.4 Baseline population density and size-structure based on transect data $\quad 20$

$\begin{array}{lll}3.2 & \text { Queen Triggerfish } & 21\end{array}$

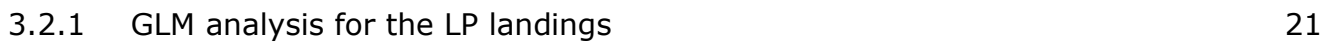

$\begin{array}{ll}\text { 3.2.2 GLM analysis for the RP landings } & 23\end{array}$

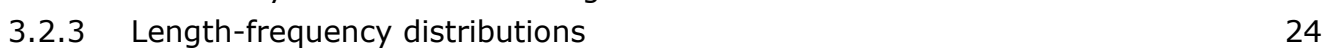

3.2.4 Baseline population density and size-structure based on transect data 26

4 Discussion $\quad 27$

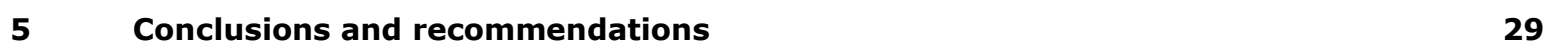

$\begin{array}{llr}5.1 \text { Conclusions } & 29\end{array}$

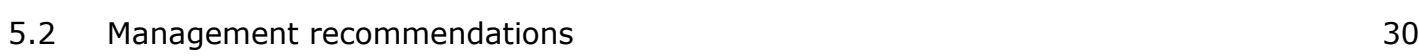

$\begin{array}{lll}5.3 & \text { Research recommendations } & 31\end{array}$

$\begin{array}{lll}\text { 5.3.1 Fisheries port sampling } & 31\end{array}$

$\begin{array}{lll}\text { 5.3.2 Fisheries-independent SPAG survey } & 31\end{array}$

$\begin{array}{lr}\text { Acknowledgments } & 32\end{array}$

$\begin{array}{ll}\text { Quality Assurance } & 33\end{array}$

$\begin{array}{lr}\text { References } & 34\end{array}$

$\begin{array}{lr}\text { Justification } & 37\end{array}$

Annex 1 : Output of the final GML models only including significant terms 38 


\section{Summary}

Based on traditional knowledge of the Saban fishermen, a spawning aggregation area (SPAG) for the Red Hind (Epinephelus guttatus) and the Queen Triggerfish (Balistes vetula) has long been known at the northeast end of the Saba Bank, locally known as the Moonfish Bank. SPAG's are very vulnerable to overfishing because these fish aggregations are predictable in space and time. Both are species of special concern throughout the wider Caribbean, due to overfishing. In 2013 a 5-year seasonal closure was arranged that prohibited fishing the Moonfish Bank from the $1^{\text {st }}$ of December to $28^{\text {th }}$ of February, within which, according to local knowledge, mass spawning takes place. The closure ended in February 2018. In this report we provide a preliminary evaluation of the effect of this 5-year seasonal closure on Red Hind and Queen Triggerfish populations of the Saba Bank based on the monitoring of fishes landed in the Saba Port in those 5 years, throughout the year. For both focal species we examined annual differences in the length-frequency distributions and Landings Per Trip (LPT; number of fish landed per fishing trip) from bycatches in both shallow $(\sim 30 \mathrm{~m})$ lobster traps and deep $(\sim 100 \mathrm{~m})$ snapper trap fisheries, using port landing data from 2011, which is prior to implementation of the closure measure in 2013, until September 2018.

Our preliminary assessment by means of Generalized Linear Model (GLM) analysis gives no indication of any improvement in LPT or mean size caught for either of the two species examined since the seasonal closure was initiated in 2013. Results even suggest a small but significant decrease in the size of Red Hinds caught as by catch in the lobster pot fishery. This means that, based on the port sampling method used, no significant positive effect on the Red Hind and Queen Triggerfish populations of the 5-year closure can yet be demonstrated. There are many possible explanations for this result, which are presented in the discussion. In particular, there is reason to believe that the current closure area may not be large enough to properly protect the Moonfish Bank SPAG and that there likely are other SPAG's on the Saba Bank that may also need protection. Therefore, further fisheries-independent research on these and other matters is needed on which basis it may be possible to improve protection so that positive evidence of the effectiveness of the closure may be documented in the future.

Based on fisheries-independent visual diver surveys in the shallow ( $\sim 20 \mathrm{~m}$ depth) coral reef zone of the Saba Bank edges in 2011, 2013 and 2015, the current population status of our focal species (in that limited habitat zone of the Bank) is as follows: Red Hinds averaged $118.7 \pm 53.5$ (ind. ha-1) with a mean size of about $24 \mathrm{~cm}$, while Queen Triggerfish averaged $56.0 \pm 37.6$ (ind. ha-1) with a median size of about $29 \mathrm{~cm}$ (data of 2011, 2013 and 2015 combined). For both focal species, the median size landed in the fishery (Red Hind: about 31 or $33 \mathrm{~cm}$ depending on the type of fishery pots; Queen Triggerfish: $34 \mathrm{~cm}$ ) was considerably larger than the mean size of the population on the reef based on surveys along the available coral reef transects. This is generally to be expected as fishing gears and fisheries typically select for larger individuals. We cautiously suggest that compared to many other areas in the Caribbean (e.g. Bonaire and Curaçao) where the Red Hind and the Queen Triggerfish once were common but now have disappeared, the populations of both these species living in the shallow coral reefs of the Saba Bank still seem relatively healthy in terms of both population density and sizestructure.

Based on experiences elsewhere in the region, there is no question that protection of spawning aggregations is a basic need for sustainable management and fishery production in mass-spawning species. Therefore, our main management recommendation is that the closure should continue. However, to reliably asses the effect of seasonal closure and to further improve protection of the spawning grounds for these species, more intensive and consistent data is needed from port sampling which should also (minimally) include data on sex and maturity of the landed fish, even though such data fall outside the typical scope of routine fisheries port sampling. Most critically, directed fisheriesindependent research will be needed to answer several critical questions regarding stock status and 
when and where spawning aggregations are actually taking place, to improve the effectiveness of seasonal closures of spawning areas of Red Hind and Queen Triggerfish on the Saba Bank. 


\section{Introduction}

Fishes that form large spawning aggregations (SPAGs) are more vulnerable to overfishing because these events occur periodically at a predictable time and place, making it possible for fishermen to easily catch a large number of the same species in a short period (Sadovy de Mitcheson 2016; SRFA 2017). Based on traditional knowledge of the Saban fishermen, an aggregation area for Red Hind (Epinephelus guttatus) has long been known to exist during the winter months at the northeast of the Saba Bank, locally known as the Moonfish Bank (Munro \& Blok 2004). This spawning aggregation was confirmed and described as an important source of larval production for Red Hind on the Saba Bank (Nemeth et al. 2006). Saban fishermen have had a long-standing tradition to fish the Moonfish Bank during the winter months when Red Hind congregate and are easy to catch, and since it is also a locally-known SPAG of the Queen Triggerfish (Balistes vetula) and squirrelfish (Holocentrus adscensionis) (Meesters et al. 1996; Dilrosun 2000). Even though nowadays the West Indian Spiny Lobster, Panulirus argus, and various deep-water snapper species (Lutjanidae, jointly referred to as "redfish) have become the main target species of the Saba Bank fishery, the Red Hind and the Queen Triggerfish are still two of the three principal species in the bycatch (of both the redfish and lobster fisheries), which are landed and sold (de Graaf et al. 2017). Trap deployment in the lobster and redfish fisheries takes place at mean depths of $29 \mathrm{~m}$ and $99 \mathrm{~m}$, respectively (de Graaf et al. 2017).

The Red Hind is a grouper from the family Serranidae. The species is found in the Western Atlantic from North Carolina, USA to Paraíba, Brazil and is the most common species of Epinephelus in the West Indies. It is primarily found on shallow coral reefs or rocky bottom (Sadovy et al. 2008) up to a depth of 110 meters (de Graaf et al. 2017). Maximum sizes are typically 50 to $55 \mathrm{~cm} \mathrm{TL}$, but there are a couple of documentations of individuals reaching 62 to $72 \mathrm{~cm}$ (Luckhurst et al. 1992) and even 76 $\mathrm{cm}$ and a maximum weight of $25 \mathrm{~kg}$ (CFMC 2005). Mean total length (TL) at maturity is $25 \mathrm{~cm}$, which is reached at the age of approximately 1.5 years (Potss \& Manouch 1995) but may be larger and older depending on the area (CFMC 2005). The fish is a protogynous hermaphrodite that changes sex from female to male at a total length of 28 to $38 \mathrm{~cm}$ (Colin et al. 1987; Sadovy and Figuerola 1992). Ages of up to 11 years have been documented (Potts and Manooch 1995).

The area where the Red Hinds migrate from to the SPAG is about 100 to $500 \mathrm{~km}^{2}(5-12 \mathrm{~km}$ radius) surrounding the SPAG (Brose et al. 2005; Nemeth 2009). During their spawning season, Red Hinds form transient aggregations that feed along the migration route and at the SPAG and therefore have an influence on multiple local food webs. The species is easily approached, readily caught by hook and line and is easily speared. It is a high-quality food fish and an important food fish in the Caribbean. In general, fishing pressure is a predominant factor affecting the size, density and abundance of groupers in the Caribbean. This has resulted in successively lower catch per unit of effort for this species and a catch composition changing gradually from larger to smaller individuals (Chiappone et al. 2000). In the Western Atlantic, all-around trends in recent years have been continuing declines in abundance of mature fishes (Brule 2018). In response to these trends, fisheries for this species are regulated in Bermuda, the U.S. Caribbean and Mexico, while in the USA a total ban on taking this species has been implemented in federal waters (Brule 2018). In 2000, the mean size of Red Hind landed from the Saba Bank was $32.9 \mathrm{~cm}$ (Dilrosun 2000) and in 2009 the mean size of female Red Hinds was $31.8 \mathrm{~cm}$ and male Red Hinds was $35.4 \mathrm{~cm}$ (Kadison et al. 2009). Based on the catch composition of the Red Hinds on the Saba Bank, Kadison et al. (2009) concluded that exploitation levels for these two species by the seven active Saban fishermen was at that time still limited, as compared to other Red Hind SPAG's in the eastern Caribbean. For St. Eustatius, which lies $25 \mathrm{~km}$ east from the Saba Bank, de Graaf et al. (2017) assessed the species based on only TL and concluded that the Red Hind population around St. Eustatius was overexploited (mean size in catch: $31.6 \mathrm{~cm}$ ).

The Queen Triggerfish is a typical reef-associated fish found at depths of $2-275 \mathrm{~m}$ but usually at depths of $3-30 \mathrm{~m}$. It is found in the Eastern Atlantic at Ascension island, Cape Verde, and in the Azores and ranges south to southern Angola. In the Western Atlantic is has been reported from 
Canada down the east coast of the USA to the northern Gulf of Mexico and southward throughout the Caribbean and all the way to south-eastern Brazil. Maximum size is $60 \mathrm{~cm}$, but more common size is $30 \mathrm{~cm}$ (from Fishbase, 2020). In fish, fecundity increases exponentially with size, so that reproductive value of larger fish is much higher than that of smaller fish. For the Queen Triggerfish, the mean size at maturity is roughly around $23.5 \mathrm{~cm}$ TL (from Fishbase, 2020). Menezes (1979) estimated size at first maturation at about $20 \mathrm{~cm}$ in terms of fork length (FL), which represents a mean age of about 2 yr. Lengths at 50\% sexual maturity (L50) for males sampled from Puerto Rico and St. Croix, U.S. Virgin Islands, were 20.6 and $21.1 \mathrm{~cm} \mathrm{FL}$, respectively and were significantly smaller than those for females (Puerto Rico: $25.6 \mathrm{~cm}$ FL; St. Croix: $24.5 \mathrm{~cm} \mathrm{FL}$ ). Ages of up to 14 years have been documented (Hernandez et al. 2018). Triggerfishes typically exhibit a relatively unusual mating strategy characterized by lek-like spawning systems in which a male establishes and defends a nesting territory (Gladstone 1994).

In the U.S. Virgin Islands fisheries, the Queen Triggerfish comprised about $22 \%$ by weight of the total trap catch of the islands and $10-15 \%$ of the total landings (Manooch and Drennon 1987). Today it remains a key commercial and recreational fishery species in many areas of the Caribbean, such as in Puerto Rico and the U.S. Virgin Islands (e.g. Hernandez et al. 2018, McCarthy 2012), where it is the top commercial demersal reef fishery species. Notwithstanding its commercial significance, the Queen Triggerfish is an extremely data-deficient species due to the lack of species-specific biological data (Hernandez et al. 2018) and very little remains known about its fisheries biology. Like the Red Hind, the species used to be common in Bonaire and Curaçao, even allowing a targeted recreational fishery (Debrot and Nagelkerken 2006) but has almost totally disappeared from the catches, primarily due to overfishing (Debrot and Criens 2005, Vermeij et al. 2019). Today, the Black Durgeon, Melichtys niger, is the only triggerfish species that is still abundant enough at selected locations in the Leeward Dutch islands to allow meaningfully targeted sportfishing. Due to widespread over-exploitation, the Queen Triggerfish is of international concern and has been categorized by IUCN as "Near Threatened" (NT) (Liu et al. 2015). Elsewhere in the Wider Caribbean the related Gray Triggerfish, Balistes capriscus, has been found to be sensitive to overfishing and for the U.S. Gulf of Mexico a management plan has been established (GMFMC 2017). In Puerto Rico landings of the Queen Triggerfish have declined relatively steadily since the 1980 s to about one-third of their initial landings in 2011 (McCarthy 2012). In the Gulf of California landings of the related species, the Fine-scale Triggerfish, Balistes polylepis, also appears to be approaching an overfished state (Monge 2012). Hence, it appears that triggerfish in general are sensitive to overfishing. On the Saba Bank triggerfish are still relatively common (Toller et al. 2010), average $34 \mathrm{~cm}$ TL in catches, have a population density of 56 ind. ha ${ }^{-1}$ in shallow reef habitat (this study) and also form an important part of the bycatch of the lobster and snapper trap fisheries (de Graaf et al. 2017).

Elsewhere, overfishing of SPAGS has frequently resulted in declining fish stocks and has even lead to endangerment of species (Jackson et al., 2001; Sadovy de Mitcheson 2016). An example is the Nassau grouper (Epinephelus striatus), which is a species of grouper similar to the Red Hind, which is now one of the species that is listed in the IUCN red list as 'Endangered' due to the overfishing of their SPAGs throughout the Caribbean (Cornish \& Eklund 2003; Sadovy de Mitcheson et al. 2008). Proper management and protection of SPAGs is essential to help guard fish species from overfishing (Linardich et al. 2017; de la Guarda et al. 2018). Uncontrolled fishing on SPAGs can totally disrupt reproduction, lead to a loss of the SPAGs and a decline and endangerment of the species concerned.

To protect the SPAG of the Red Hind (and fortuitously also Queen Triggerfish for which, according to local knowledge, spawning aggregation occurs in the same area and during the same "winter" period) on the Moonfish Bank of the Saba Bank, a fishing ban was arranged by Ministerial Decree in 2013 that prohibited fishing the Moonfish Bank from the 1st of December to 28th of February for five years (Staatscourant 2013). This followed the example of other seasonal fishing bans for the Red Hind in the region. For instance, in 1987 a seasonal closure was arranged for the Red Hind SPAG at St. Thomas, US Virgin Islands. As a result, the mean size of Red Hind increased from $29.5 \mathrm{~cm}$ up to $39.0 \mathrm{~cm}$ over a period of twelve years. This was followed by a permanent closure that resulted in a nearly $7 \mathrm{~cm}$ increase of total length of the male Red Hind in a time span of an additional five years (Nemeth et al. 2006). Likewise, a properly implemented and enforced seasonal closure in St. Croix, resulted in an increase in the mean Queen Triggerfish TL from $32.5 \mathrm{~cm}$ to $38 \mathrm{~cm}$ (Nemeth et al. 2006). In Bermuda, 
seasonal closure of spawning aggregations lead to a recovery of Red Hind stocks after only 2 years (Luckhurst et al. 1992); Luckhurst and Trott 2009). In Puerto Rico, the Department of Natural Resources has prohibited the take of Red Hind during the spawning season, running from December until March, since 2004. However, by 2008 the measure had not yet had measurable effect on mean TL of Red Hind, probably due to the lack of enforcement (Sadovy et al. 2008). In February 2018, the fishing ban on the Moonfish Bank of Saba came to an end. The purpose of this work was to provide a preliminary evaluation of the closure's effectiveness and to make management recommendations. (In the meantime we can report that based on a preliminary draft of this report, the measure has been extended for another five years and ends on the $1^{\text {st }}$ of March of 2023).

The objectives of this study were to assess a few key questions regarding the Saba Bank seasonal closure:

a) what, if any, has the effect of the closure been on the Red Hind and on the Queen Triggerfish in terms of mean size caught or in Landings Per fishing Trip, LPT)

b) does it need to be continued, and if so

c) how, and finally

d) what recommendations can be made to allow a better assessment of the effectiveness of the closure on target species populations.

The roles fulfilled in producing this report were as follows: Thomas Brunel, analysis and writing of key results; Jessica Schop: analysis and graphics; Y. Bakker: preliminary analysis and writing; $A$. Kuramae, : data collection, field coordination and review; A. O. Debrot: project leadership and writing. 


\section{Materials and Methods}

\subsection{General approach}

During the planning stage we had decided to use fishery-independent data collection to address the questions regarding the seasonal closure. There are many advantages to using fishery-independent data. This is because fishery catches are subject to many factors beyond control of the researcher, whereas fishery-independent studies can be planned and executed with more care and precision. Such data can often be more precise with respect to size measurements and site determination and allow for direct population density estimation. Consequently, they often provide a more direct and precise measurement of population status than fishery catches. Hence, fishery-independent data are typically superior in quality and allow for better inferences regarding population trends. For instance, as pointed out by Jarvis et al. (2004) and Cushion et al. (2007) the many confounding factors influencing fisherydependent data, make it difficult to judge whether changes in catch data represent actual population changes. However, due to field technical limitations, it was impossible to actually conduct the desired field sampling and this report largely suffices with a preliminary analysis of fishery-dependent data instead.

The rationale in using this approach is as follows:

If a species is already overfished, implementing a fishing closure to protect its spawning aggregation should be expected to lead to:

- a gradual increase in fish numbers and population density

- a gradual increase in fish size in the population.

By extension, under such circumstance one would also expect to see a gradual increase in:

- $\quad$ mean Landings Per Trip (LPT) in the fishery

- $\quad$ mean fish size landed in the fishery

Therefore, we used port landing data from 2011 to 2018 to examine LPT (number of fish landed per fishing trip) and size-structure in catches over these years, to gain insight into possible gradual changes in actual population status, since the closure of the Moonfish Bank in 2013. LPT as we use it is just one variant of the more commonly known concept of Catch Per Unit Effort (CPUE). Often, there is a difference between the fish caught and those landed. In such cases CPUE may be more appropriately labelled as "LPUE" (Landings per Unit Effort). Different units of "effort" may also apply, such as "boat days", "man days", "trap days", "trap lifts" or "trips". Because landings per trip is the measure of greatest relevance to the fisherman, our main analysis was based on landings per trip (LPT). For part of the presentation we also used graphs of LPUE based on landings per trap ( $\mathrm{nr}$. fish/pot), which is simply a different index of the more traditional and better-known "CPUE".

Thanks to several recent coral reef monitoring expeditions to the Saba Bank (e.g. Beek and Meesters 2013, 2014) we can also provide some limited fishery-independent data from which to gain some additional insights on possible developments in population densities of Red Hind and Queen Triggerfish, that could have taken place in response to the seasonal spawning grounds closure.

\subsection{Study area}

The main data for this research was collected at Fort Bay, home port of fishing vessels that use the Saba Bank as their fishing grounds (circa 2,200 km², Figure 1). Port fisheries sampling followed the FAO guidelines for subsampling for general fisheries monitoring (Stamatopoulos 2002). The two main data sources used for this study consisted of information obtained through short interviews and species composition sampling. Short interviews provided information such as, boat, gear type, number 
of gear, fishing duration, fishing area, total landings for each trip. In total 3557 interviews were available between 2011 and 2019 .

The Saba Bank is located $5 \mathrm{~km}$ southwest of Saba and $25 \mathrm{~km}$ west of St. Eustatius. It is a submerged atoll with a depth to 200 meters. The largest part of the Bank lies between of 20 to 50 meters depth (de Graaf et al 2017). The south-eastern edge of the Bank consists of coral reef of about $55 \mathrm{~km}$ long (van der Land 1977). There is as yet not so much known about the biodiversity and ecology of the Saba Bank (de Graaf et al. 2017). Toller et al. (2010) reported sightings of Red Hinds on fore reef, outer reef flat, inner reef flat, lagoon soft bottom and lagoon hard-bottom in an Saba Bank area similar to the SPAG.

One-third of the Saba Bank lies in the Saba territorial waters and $1.3 \%$ within the territorial waters of St. Eustatius. The rest of the Saba Bank lies in the Exclusive Economic Zone of Saba. In 2010, The Saba Bank National Park $\left(2680 \mathrm{~km}^{2}\right)$ was established to safeguard the wealth of biodiversity on the Bank, managed by the Saba Bank Management Unit a part of the Saba Conservation Foundation (DCNA 2018).

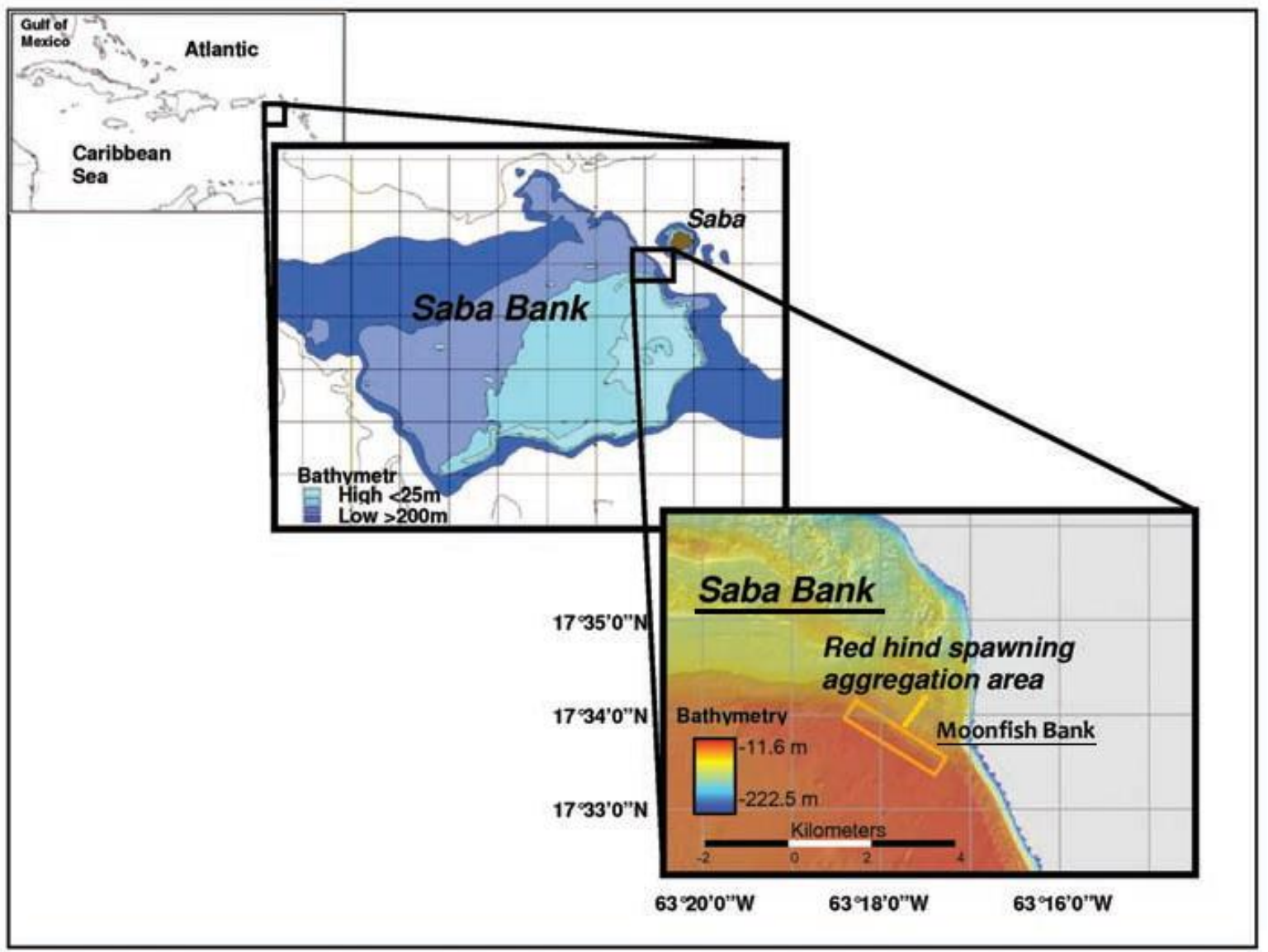

Figure 1. Bathymetric chart of the Saba Bank (Caribbean Netherlands) and the location of the Red Hind SPAG located on the Moonfish Bank (Kadison et al. 2009).

The area that was closed for fishing from the $1^{\text {st }}$ of December to the $28^{\text {th }}$ of February surrounds the Moonfish Bank. The choice for the period of closure was based on anecdotal data and not verified by either fecundity data or actually field aggregation data.

\subsection{Distribution of fishing effort on the Bank}

Fishing with pots to target either spiny lobster or redfish takes place throughout the Bank. However, lobster traps have a mean fishing depth of $29 \mathrm{~m}(\mathrm{~N}=443)$ and the red fish traps a mean fishing depth of $99 \mathrm{~m}(\mathrm{~N}=659)$ (de Graaf et al. 2017). 
There are six key areas where Red Hinds and Queen Triggerfish are caught in traps, coinciding with the areas of main fishing effort distribution on the bank (B3, B4, B5, C4, C5, D3 and D5). Fishing area B4 $(N=402)$ and B5 $(N=452)$ were also the areas where most Red Hinds were caught based on the

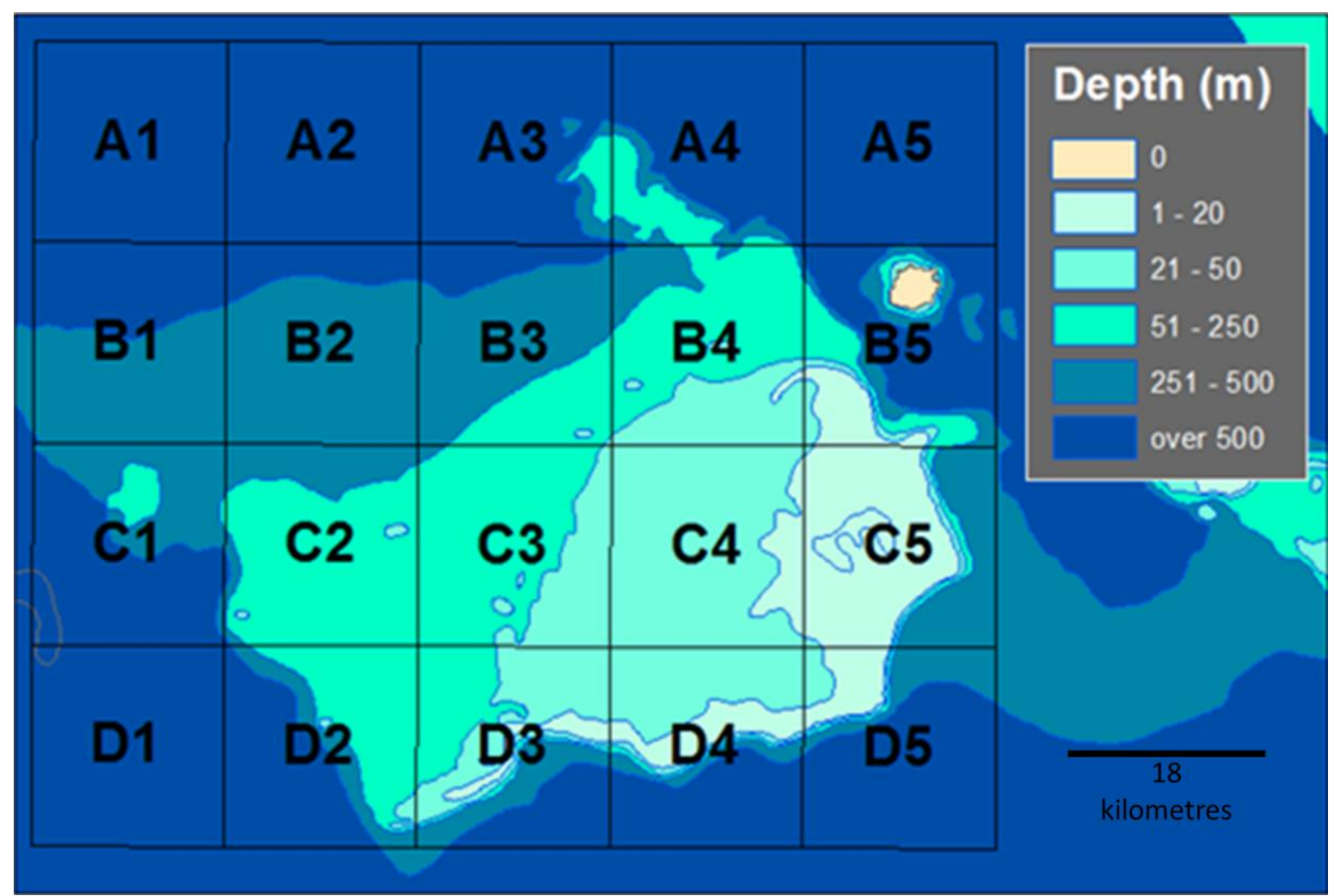

Figure 2. Overview of the Saba Bank with the 20 sub-areas used in the fishery monitoring scheme (map from de Graaf et al. 2017).

number of fishing trips. Of all catches in B5 in 2018 (where the Red Hind SPAG is located), 73.9\% was caught in the month of February. The northern sections of the bank (B3-B5) showed the highest LPT in 2018.

\subsection{Port sampling}

The total length ( $T L$ ) of the fish was during port sampling measured by putting the fish straight and horizontally on a measuring board. The TL-measurement was from the tip of the snout to the end of the caudal fin. Species name and TL of the fish was noted in centimetres to the nearest centimetre (de Graaf et al. 2017). On the "Length-frequency data form" the date, year, month, boat name, fishing gear and number of traps, fishing area and depth were also noted per fishing trip. All this latter information was provided by the fishermen whereas the size measurements were collected by the Data Management Officer.

\subsection{Data preparation}

Port-sampling data (density and TL per species per fishing trip) of all the years (2011-2018) were combined into one data sheet for further analysis by means of the software R (R Core Team 2017). Data was examined for correct labelling, by gear, date, fishing area and boat name. The data from 2011 was very incomplete and thus ultimately excluded from further analysis. In the end, the total fishing trips on which our analysis is based was reduced from 426 to 304 trips after basic data 
cleansing. The cleansed data concerned a total of 215 lobster pot (LP) trips and 89 redfish pot (RP) trips on which to base further analysis (Table 1 ).

Table 1. Total number of fishing trips per fishing gear (lobster pot (LP) or redfish pot (RP)) per year after data selection, and total number of caught fish, Red Hind and Queen Triggerfish for which length $(\mathrm{cm})$ was measured.

\begin{tabular}{|c|c|c|c|c|c|c|c|}
\hline & 2012 & 2013 & 2014 & 2015 & 2016 & 2017 & 2018 \\
\hline \# LP trips & 37 & 29 & 29 & 54 & 26 & 27 & 13 \\
\hline $\begin{array}{l}\text { \# all measured fish } \\
\text { from LP }\end{array}$ & 3095 & 1736 & 2352 & 2881 & 1246 & 3300 & 3480 \\
\hline $\begin{array}{l}\text { \# measured Red } \\
\text { Hinds from LP }\end{array}$ & 71 & 44 & 71 & 29 & 4 & 161 & 101 \\
\hline $\begin{array}{l}\text { \# measured Queen } \\
\text { Triggerfish from LP }\end{array}$ & 50 & 23 & 80 & 42 & 8 & 114 & 126 \\
\hline \# RP trips & 15 & 22 & 22 & 9 & 11 & 5 & 5 \\
\hline $\begin{array}{l}\text { \# measured fish } \\
\text { from RP }\end{array}$ & 3473 & 3030 & 3542 & 4018 & 2757 & 844 & 3932 \\
\hline $\begin{array}{l}\text { \# measured Red } \\
\text { Hinds from RP }\end{array}$ & 98 & 75 & 166 & 76 & 113 & 27 & 91 \\
\hline $\begin{array}{l}\text { \# measured Queen } \\
\text { Triggerfish from } \\
\text { RP }\end{array}$ & 9 & 24 & 10 & 5 & 16 & 2 & 5 \\
\hline
\end{tabular}

\subsection{Analysis}

All the data of TL-frequency was combined in box-plot graphs to visualize potential trends over the seven years from 2012-2018, as an aid to data exploration. In the box plots, the rectangle is the inter quartile range (IQR), with the bar at the centre being the median, the bars at the end of the whiskers are the maximum and minimum values, excluding the outliers. The points are the outliers. Any value that is larger than third quartile $+1.5^{*}$ IQR is considered an outlier and then the maximum is calculated excluding these outliers).

LPUE was calculated per focal species per fishing trip by dividing the total number of each focal species landed during a fishing trip by the number of traps lifted during that trip. Next, LPUE was used to look for difference in catch efficiency between lobster and redfish traps in order to determine whether lobster and redfish trap data should be analysed separately.

In this study we used time series of landings per fishing trip (LPT) as proxy for the population size of exploited fish stocks. However, variations in LPT might reflect other factors than changes in fish abundance. In the case of reef fish trap fisheries, these factors may include, the number of fishing pots that were collected per fishing trip (the basic unit of effort), the soaking time of these fishing pots (i.e. the time between pot deployment and pot collection), the year or month when pots were collected, the area were pots were collected, or the fishing boat that deployed the fishing pots. These additional factors should also be taken into account when aiming to test whether fish abundance may have increased since the seasonal closure of the Moonfish Bank in 2013. A common way to extract the part of the variation that is due to abundance variations only, is to fit a generalised linear model (GLM), including as model components all the factors mentioned above that could possibly affect the number of fish landed per trip (LPT).

The formulation of the full model used for both Red Hind and Queen Triggerfish is as follows: 
$\log ($ LPT $)=$ intercept + Year effect + Month effect + Boat effect + Soaking Time $+\log (\mathrm{nr}$. of pots lifted per trip)

In this formulation of the model, the parameters estimated are :

- $\quad$ one parameter for the intercept

- $\quad$ one parameter for each of the levels of the different effects (year, month, boat).

- $\quad$ one parameter for the linear regression of $\log ($ LPT) against log(nr. of pots lifted per trip).

- $\quad$ One parameter for the linear relationship with soaking time

The "Year" effect estimated by this method correspond to the variations in the landings which are explained by the year, when all other sources of variation have been taken into account (including the changes in effort). These year effects can therefore be interpreted as temporal effects on abundance. The effect of trap numbers could have been accounted for by modelling the landings per trap, instead of per trip. However, this would imply a direct proportional (linear) relationship between landings per trip and number of traps. In the case of trap fisheries, there might be competition between traps (e.g. if the area of attraction of 2 traps overlap), and therefore increasing the number of traps would not necessarily mean an increase in catch in the same proportion. The model formulation chosen implies a power function $\left(y=a x^{b}\right)$ between the landings and the effort. If indeed there is competition between traps, the value of $b$ is excepted to be smaller than 1 . This has been observed for instance in a similar GLM model for lobster on Saba, where the estimated parameter value was 0.77 (Brunel et al, 2018).

Another factor that could potentially influence the landings per trips (LPT) was the geographical location of the fishing pots. The fishing area (Figure 2) are reported for most cases in the logbooks. However, the coverage of the different fishing areas was too unbalanced to be able to include area as a factor in the GLM. For both species, a quick comparison of the landings per trip across areas suggested that there was no strong area effect of area, so that not including "Area" as a variable in the model should not introduce any bias in the effects estimated by the GLM.

This model was fitted for both species separately on the lobster pot (LP) data and on the redfish pots (RP) data. The number of catch data per Boat ID were not consistent over time. For the LP, some boats occurred only in the first years (2012-2013) and others only in the last years (2016-2018). The data from these three boats were removed from the data set to avoid introducing a bias in the year effect estimated in the GLM (since raw data suggest different mean catches per trips between boats). Likewise, for the RP, three boats were also removed. This left only a total of 143 observations for the analysis of LPT trends in the LP data and 48 for the RP data. For LP, there is a good coverage of all the months, but not for RP. For both gears, no clear seasonality can be seen from the raw data. Month can be included as a factor in the full GLM model for LP. Due to limited data per month for RP-landings, "Month" could not be used as factor in the model for RP. However, since the data didn't suggest any systematic month effect, no further (sub)selection of the data seemed necessary.

LPT data is modelled as count data. The typical distribution used in GLM for count data are Poisson, or negative binomial for over-dispersed data. A quick inspection of the distribution of the landings per trip for both species indicated that the Poisson was not appropriate because it could not cope with the high proportion of 0 values (40\% in the Queen Triggerfish case) and the occurrence of very high values. The negative binomial allowed for more zero values and at the same time, more high values, and was then used for the GML in both species. The choice of a negative binomial distribution then implied that the link function used was the logarithm (i.e., we modelled log(LPT)).

The negative binomial GLM was then first fitted for the full model as described above. Model selection was carried out by removing one by one all terms in the full model, fitting the GLM, and comparing the full and reduced models using likelihood ratio tests. If any term was none significant ( $p$-value $>0.05$ ), the term with the highest $p$-value was first removed and the GLM fitted again. This process was repeated until all remaining terms were significant. The output of the GLM were then inspected to check the validity of the model. The predicted values had a distribution quite similar to the observed values (including the percentage of 0 values) and there was no obvious trend in the residuals. 
The estimated year effects for both species were then used to look for trends in landings per trip (LPT) from January 2011 until September 2018, to investigate whether the seasonal closure of the Moonfish Bank for fisheries since 2013 had an effect on the population size of Red Hind and Queen Triggerfish.

Single factor testing for differences in mean LPUE (nr. fish/pot) and mean size per fishing gear type was done using the Kruskall-Wallis test (a non-parametric "ANOVA" procedure applicable to distribution free data sets) while a parametric one-way ANOVA was applied to log-transformed LPTdata. The Red Hind distribution on the Saba Bank (for 2018) was roughly determined by using the LPT per fishing area in combination with crude number of catches. LPT was used as an index for which zone the population was concentrated in.

For our assessment of potential changes in length-frequencies, we ultimately chose not to use a GLM approach. GLM analysis is of value when you want to model the effect of continuous variables on your response, and want to model data with a distribution other than normal. In the case of the lengths, we just wanted to know the effect of a few factors on mean length, and an analysis of variance was deemed a more appropriate test. However, after looking at the actual data available it was evident that the ability to test for many factors simultaneously was seriously limited by the low number of samples. For instance, for the Queen Triggerfish, even if we don't consider Month, Boat ID and Area effects, and investigate only Year and Fishing Gear effects, there is not enough data. For the RP catch data for Queen Triggerfish, there were very few fish measured each year (less than 10 for most years). For LP catches, there were usually more fish measured for length, but still very few for some years $(2013,2016)$. For Red Hind there were more length measurements, but still, not enough to look at the effect of Boat ID or Area or Month. For both gears, there were years with very few samples (which cannot be included in the analysis), but these years differ depending on the gear. Therefore, it is not possible to make a multi-way test including year and gear as factors at the same time to predict length-frequencies in catch data. The only test approach possible was to examine the single effect of "Year" on length-frequencies in catch data for each gear in the two species of concern.

\subsection{Fisheries independent population data}

Fisheries are generally highly selective for certain size-classes of the fished population. While there are plenty of exceptions, as a general rule fisheries for food fish will tend to selectively harvest larger fish. This means that the size-structure of landed fish will generally not accurately reflect the size structure of the fished population. To give some idea of the fished population we here present data from diverbased fish counts along transects collected as part of the Saba Bank monitoring expeditions that have been taking place every 2 or 3 years, since 2011 (Beek and Meesters 2013). In that effort, the fish faunas of a total of 11 shallow reef locations (17-32 m) along the eastern and southern borders of the bank were assessed in 2011, 2013, 2015, and 2018 (Fig. 3). As the 2018 data was not yet available, in this report we use the data collected at these transects in 2011, 2013, and 2015 to report on indicative population densities and size structures of the two species of concern. Interpretation of the results needs to be done with care, as there are several other habitats present on the bank which have different fish community densities and compositions compared to reef sites (Toller et al. 2010). The annual monitoring transects at the 11 sites comprise three sub-transects of $50 \mathrm{~m}$ length and $5 \mathrm{~m}$ width (Beek and Meesters 2013). For the purpose of our analysis data collected per sub-transect per site were pooled to obtain a single density estimate per site per year. Due to the low densities observed along the transects, for each of our focal species we pooled data on individual lengths over all the years to obtain a rough size-frequency distribution for the reef habitats on the Saba Bank. 


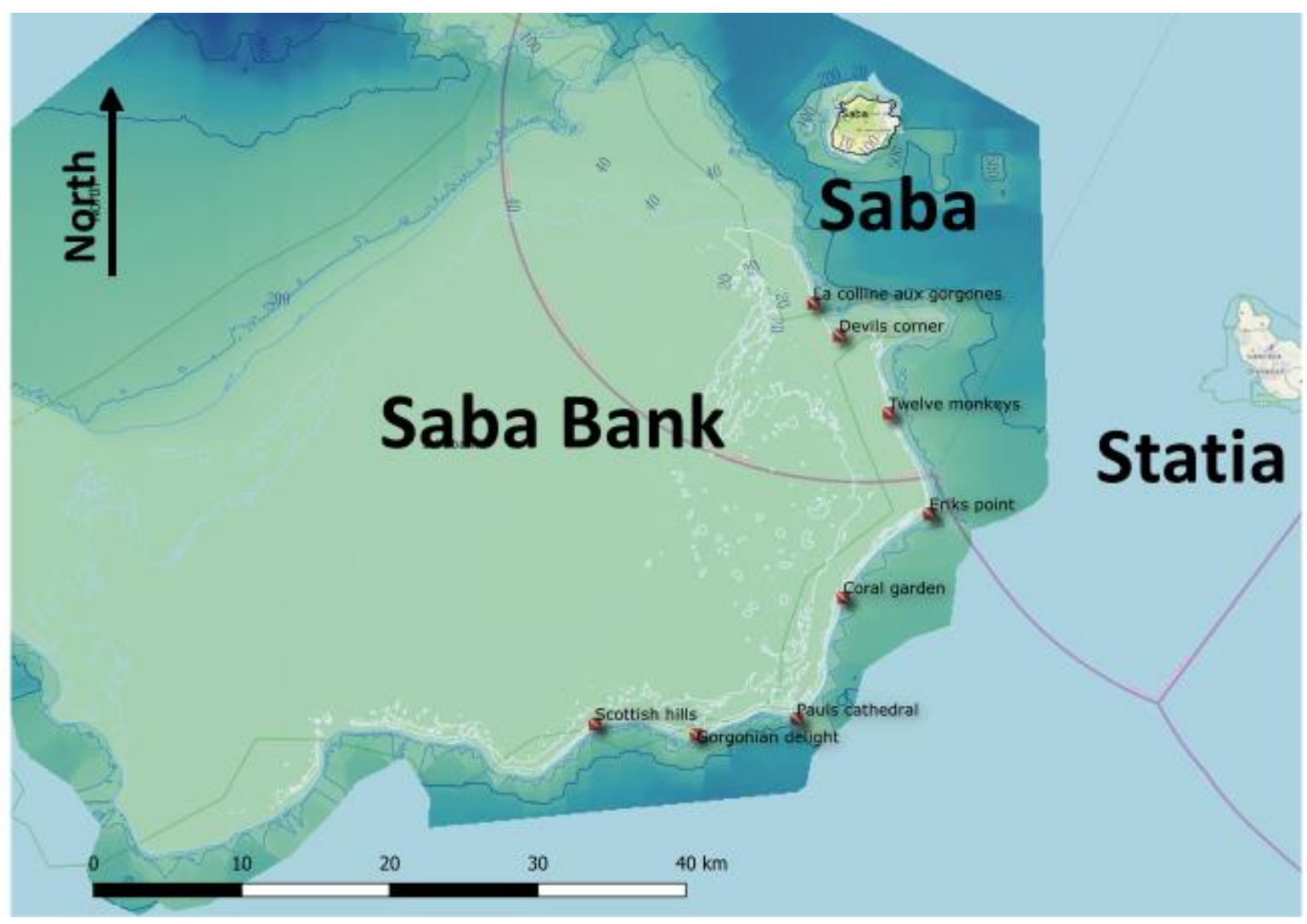

Figure 3. Bathymetry of the Saba Bank with isobath depth contour lines (Data from the Netherlands Hydrographic Service), the islands of Saba (Northeast of the Saba Bank) and St. Eustatius (East of the Saba Bank) and the 11 stations which were surveyed (Beek and Meesters 2014). Fore-reef stations were in the 17-32m depth range and the patch reef on top of the Saba Bank, Tertre de Fleur, is at $15 \mathrm{~m}$ depth. 


\section{Results}

\subsection{Red Hind}

Red Hinds were caught in both lobster (LP) and redfish pots (RP). The mean LPUE (nr. fish/pot) for Red Hinds ( \pm SD) trapped with LP was $0.140 \pm 0.496$ while the mean LPUE for Red Hind trapped with RP was $0.171 \pm 0.281$, which was somewhat higher $(22 \%)$. The difference in LPUE between gear types was statistically significant (Kruskal-Wallis $\mathrm{H}=7.2858, \mathrm{df}=1, \mathrm{p}<0.01$ ), which meant that separate analyses were conducted for the two gear types. Inspection of the distribution of the landings of Red Hind per trip indicated that a negative binomial GLM may be the most appropriate.

\subsubsection{GLM analysis for the LP landings}

For the lobster pot (LP) data, the final GLM for Red Hind included the effects of Soaking Time, Boat ID, Month and Year. The distribution of the predicted values was also very similar to the observed data (including the proportion of 0 values). The value of the estimated model parameters and associated $p$ values are given in Annex 1a. The GLM indicated that the number of Red Hind landed per trip (LPT) decreased significantly with trap soaking time ( $p=0.03$, Fig. 4 ). Boat ID and Month also significantly explained some of the variation in LPT (Fig. 4). There seemed to be some seasonality in the landings, with period of lower values broadly between November and April, and higher values during May to October (Fig. 4). LPT also varied significantly between years (Fig. 4, Annex 1a). We did not perform a post-hoc test, but visual inspection of the data indicated a stock that decreased to a low value in 2015 and increased subsequently until 2017, to decrease to an average value in 2018 (Fig. 4, see also Fig. 5).

In order to perform a formal statistical test for the existence of a temporal trend in the abundance of red hind after the closure, A GLM model was also fitted using "Year" as a linear predictor. After model selection, this GLM included the effect of month and boat ID only. This indicates that there was no linear trend in the LP-landings per trip of red hind over 2013-2018.
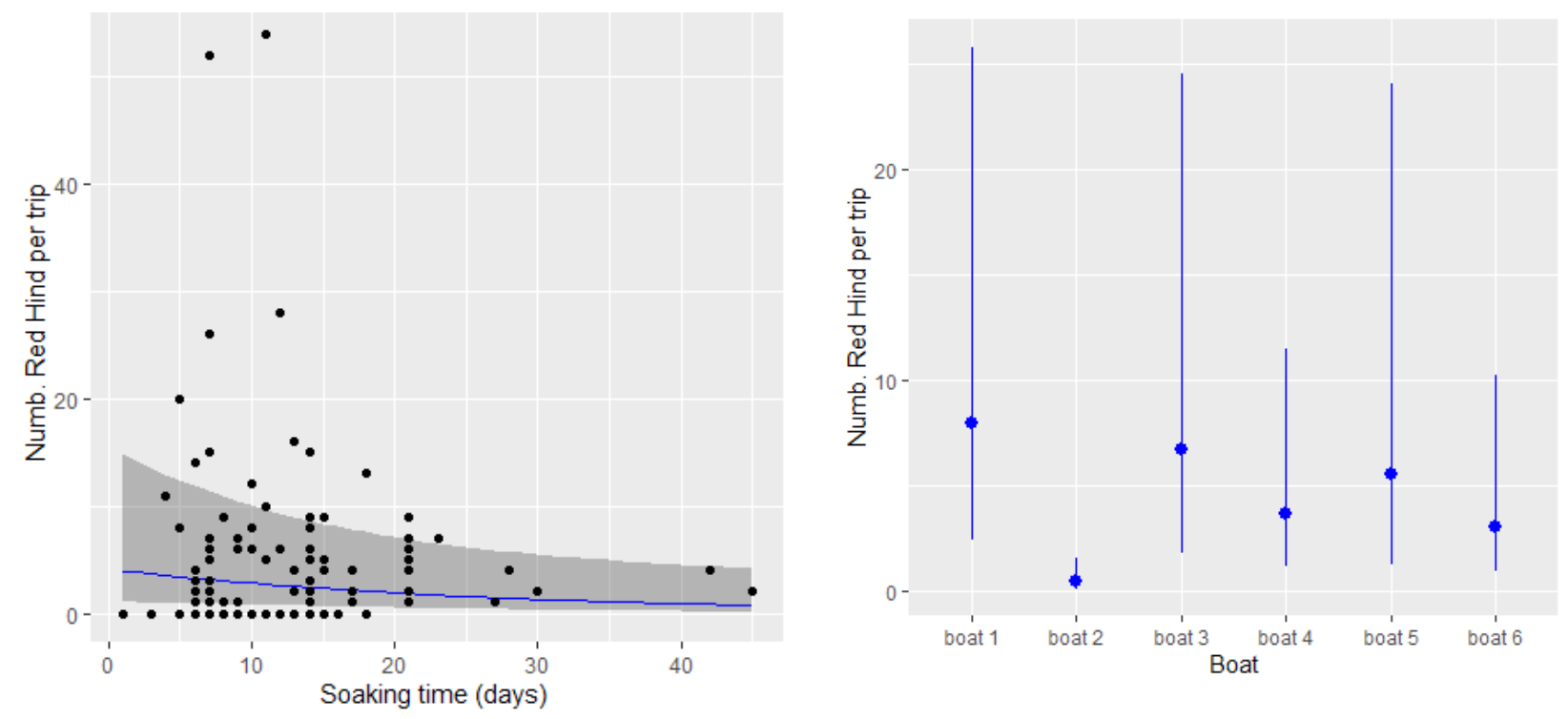

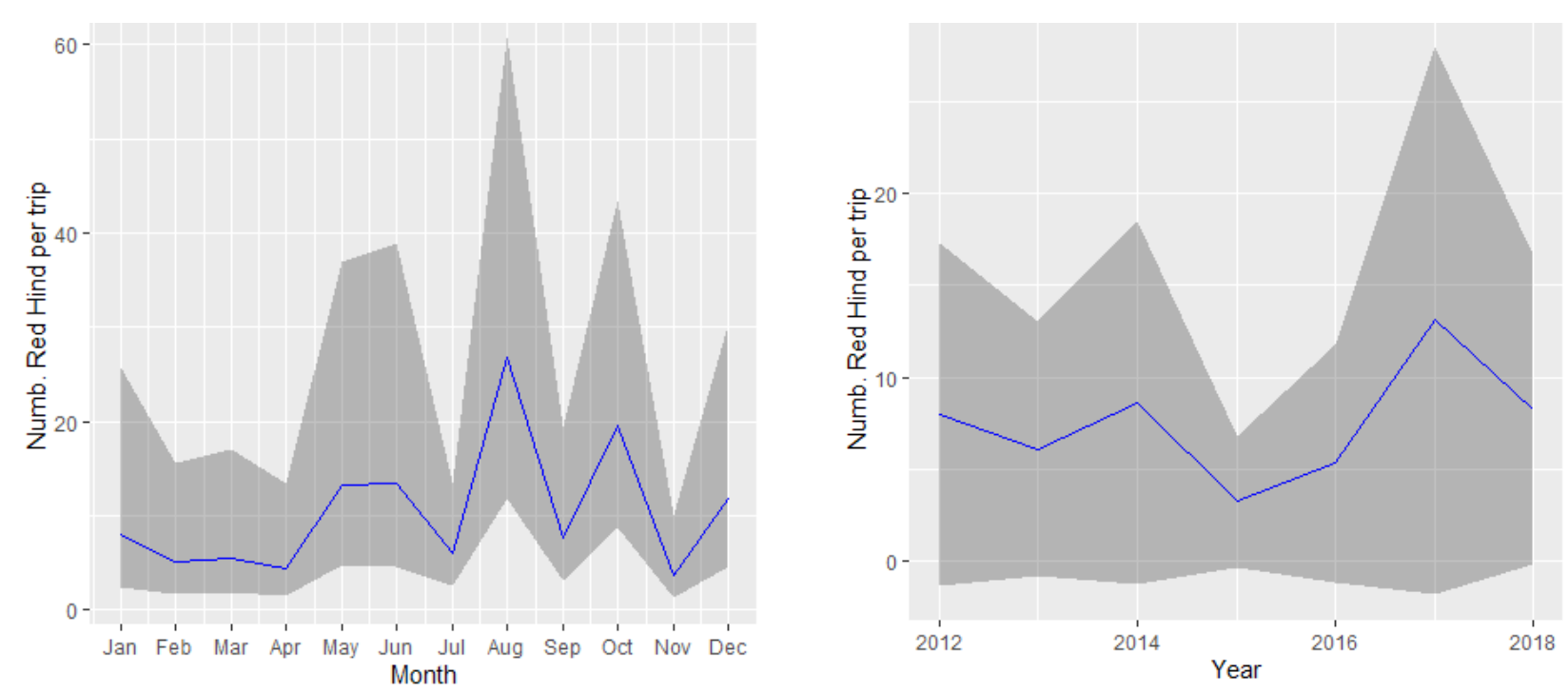

Figure 4. Estimated effect and $90 \%$ confidence intervals of (a) soaking time, (b) boat, (c) month, and (d) year, on LP landings of Red Hind (nr. of fish landed per fishing trip).

Red hind with LP
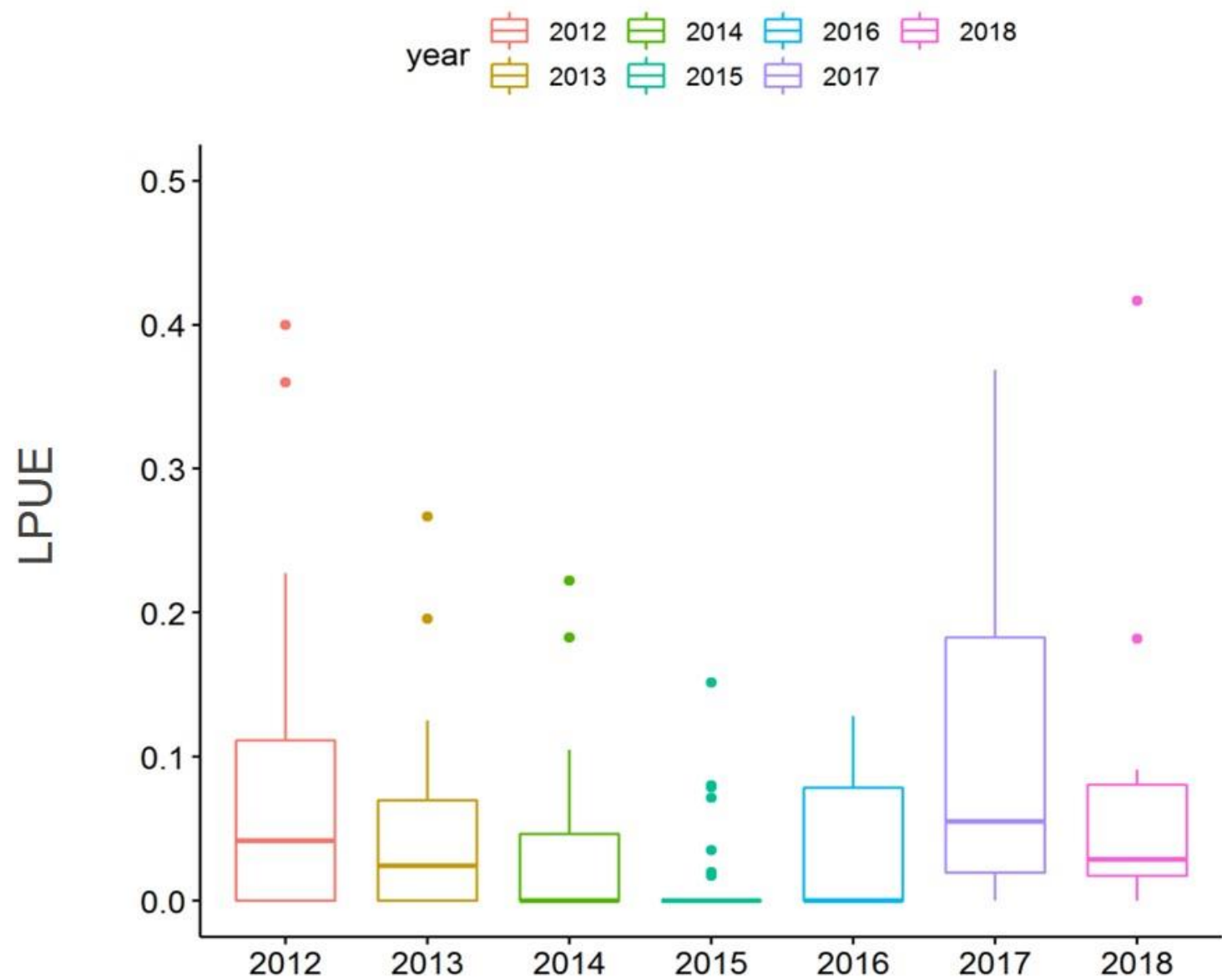

Year

Figure 5. Box plot showing the number of Red Hind landed per lobster pot (LPUE) as a function of calendar year for the Saba Bank. Box plot shows interquartile range, median, maximum and minimum values, and outliers. 


\subsubsection{GLM analysis for the RP landings}

None of the terms in the GLM of the RP landings were significant for the Red Hind. Figure 6 shows a box plot of number of Red Hind landed per redfish pot (LPUE) per year.

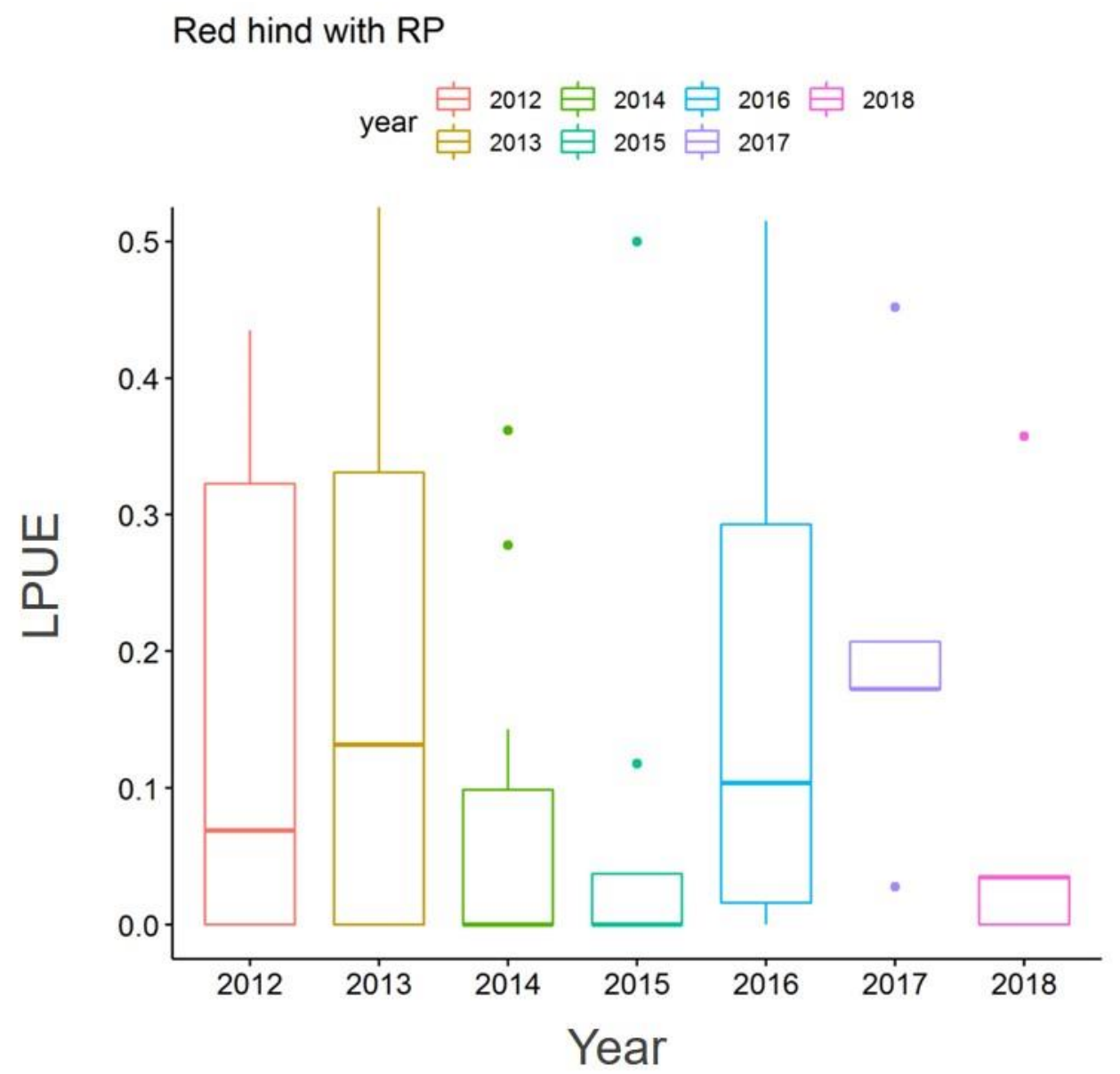

Figure 6. Box plot showing the number of Red Hind landed per redfish pot (LPUE) as a function of calendar year for the Saba Bank. Box plot shows interquartile range, median, maximum and minimum values, and outliers.

\subsubsection{Length frequency distribution per fishing gear}

Figure 7 shows the size frequency structure for all Red Hinds recorded from the Saba Bank fishery for both gear types. A comparison of size between gear types showed a statistically significant $2 \mathrm{~cm}$ difference in median size between the two gears (Kruskal-Wallis $\mathrm{H}=19.941,1 \mathrm{df}, \mathrm{p}<0.001$ ). Hence, the actual comparisons of sizes caught over time were done separately for the two gear types (Fig. 8, 9). A one-way ANOVA test indicated a significant difference between years in the mean length in Red Hind caught for both lobster pots $(p<0.001)$ and redfish pots $(p=0.04)$. Fitting a linear regression model for total length against year indicated a significant decrease in fish length over time for the catches in lobster traps (slope of $-0.56 \mathrm{~cm} / \mathrm{y}, \mathrm{p}<0.001$; Fig. 8) but no trend for redfish traps $(p=0.21$; Fig. 9). 


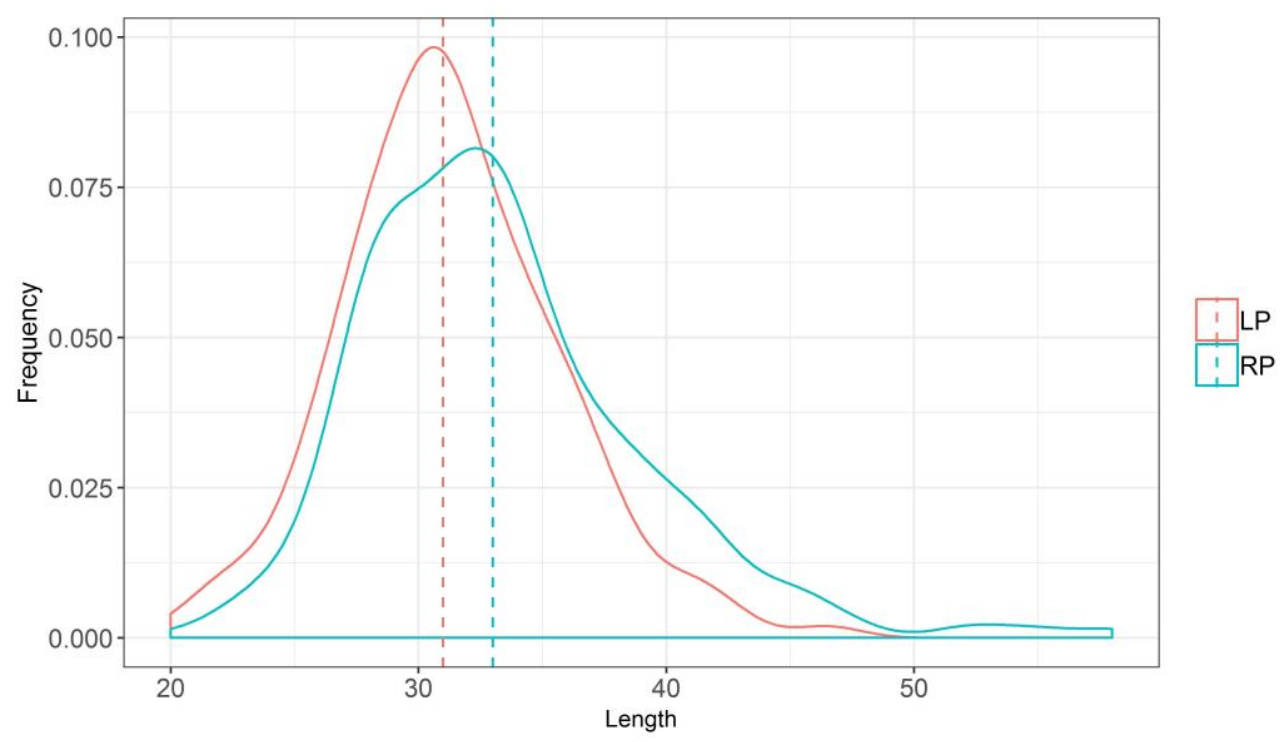

Figure. 7. Comparison of total length (cm) of Red Hind caught between 2012 and 2018 between two fishing gears (i.e, lobster pot (LP) and redfish pot (RP)). Median length for LP and $R P$ are indicated by dashed line (respectively, 31 and $33 \mathrm{~cm}$ ).

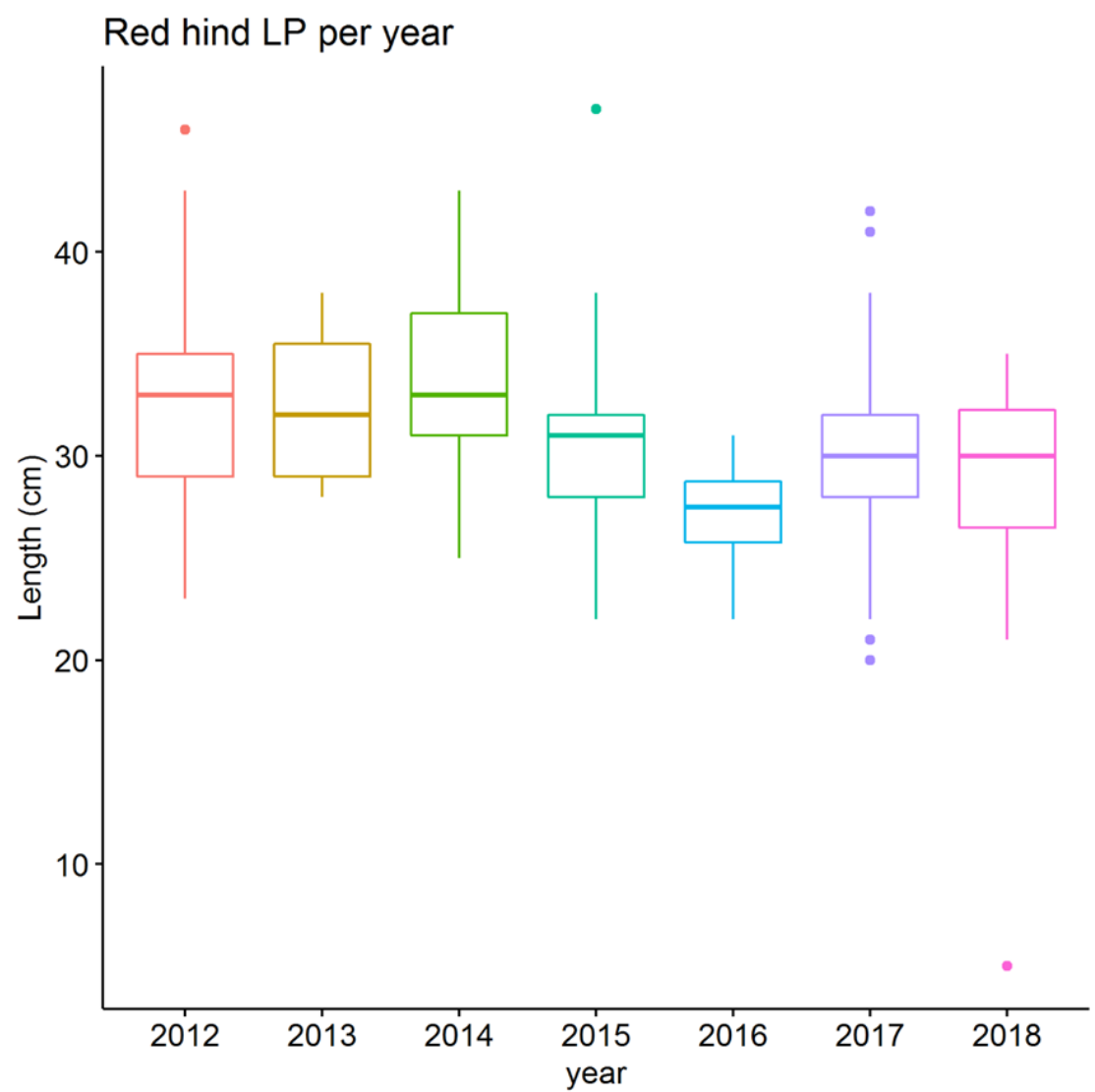

Figure 8. Box plot showing total length per year for Red Hind caught on the Saba Bank with lobster pots (LP). Box plot shows interquartile range, median, maximum and minimum values, and outliers. 


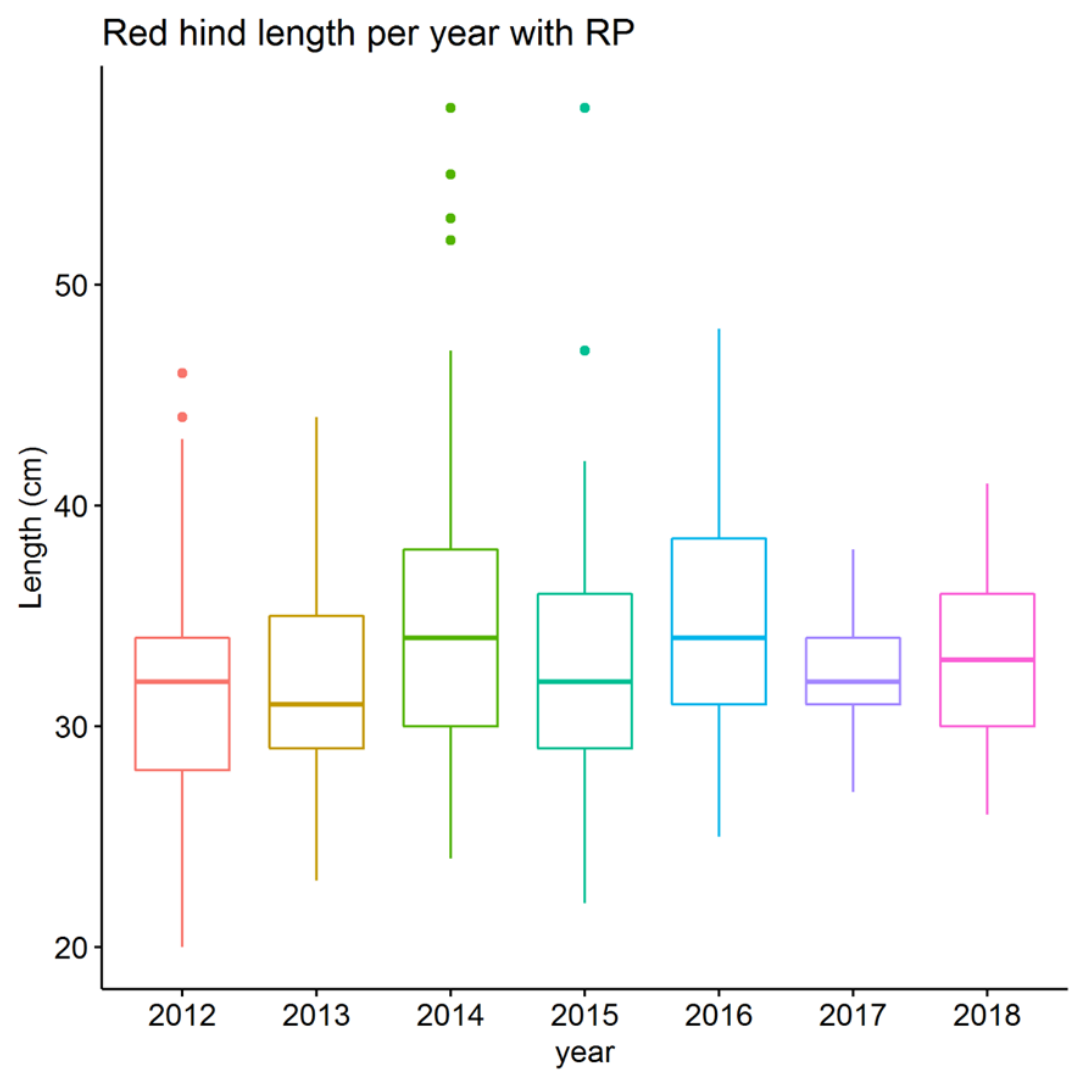

Figure 9. Box plot showing total lengths per year for Red Hind caught on the Saba Bank by redfish pots (RP). Box plot shows interquartile range, median, maximum and minimum values, and outliers.

\subsubsection{Baseline population density and size-structure based on transect data}

Baseline population density estimates for Red Hinds in coral reef habitat sites averaged $118.7 \pm 53.5$ SD (ind. ha-1) (data pooled for 2011, 2013 and 2015). The mean size of the fish observed during the diver fish-count transects carried out in 2011, 2013 and 2015 was somewhat less than $25 \mathrm{~cm}$ (Fig. 10), which is considerably smaller than the $35 \mathrm{~cm}$ mean size of the fish reported in the landings (which is larger than the median sizes plotted in Fig. 7). Unfortunately, sample sizes were very limited, representing only one shallow habitat and given only in $5-\mathrm{cm}$ size intervals. While these data are of value for long term monitoring purposes when identical monitoring methods are applied in the future, little can be said at this point other than that the fishes landed are about $10 \mathrm{~cm}$ in TL larger than the fishes found in the sampled coral reef habitat (only one of several habitat in which the Red Hind is found). 


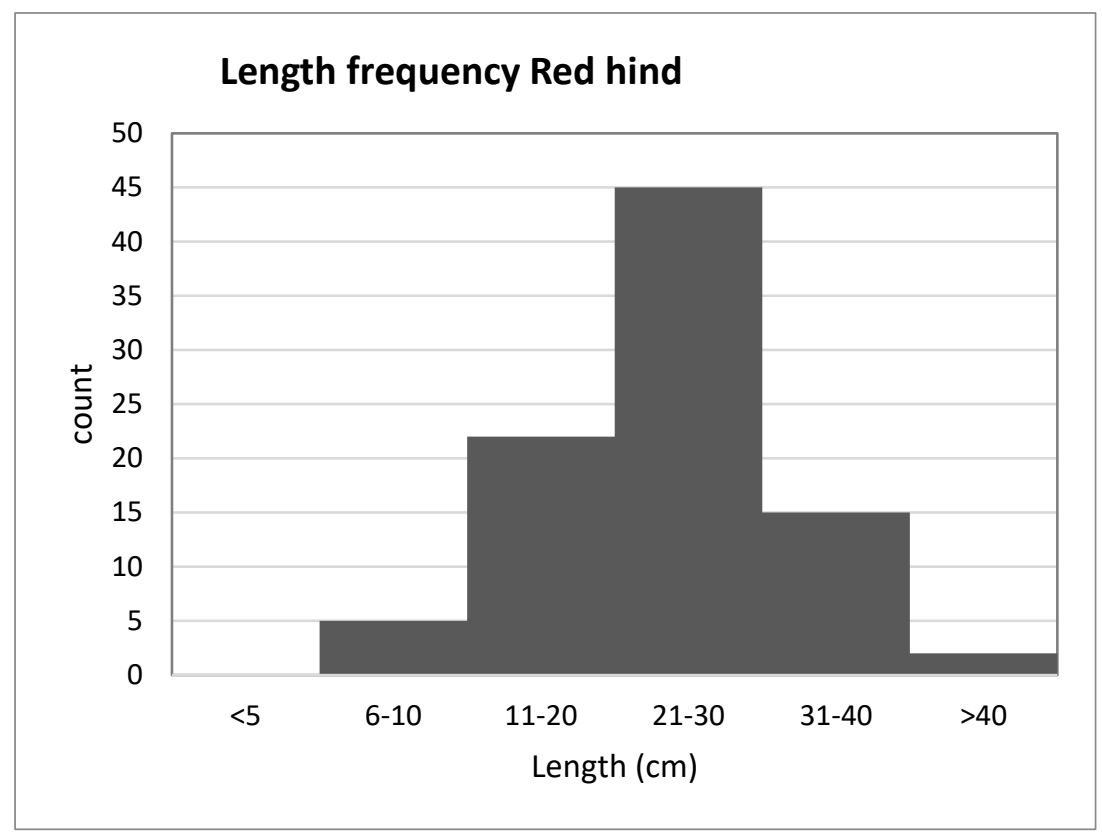

Figure 10. Frequency distribution of total length (TL) for the Red Hind observed during fishcount transects in shallow coral reef habitat on the Saba Bank averaged for 2011, 2013 and 2015.

\subsection{Queen Triggerfish}

Queen Triggerfish were also trapped in both types of fishing pots. The mean LPUE (nr. of fish /pot) for Queen Triggerfish ( \pm SD) trapped with lobster pots (LP) was $0.133 \pm 0.462$, while the mean LPUE for Queen Triggerfish trapped with redfish pots (RP) was $0.0254 \pm 0.0576$, which was remarkably lower. This results contrasts with Red Hinds, for which LPUE was higher for fish trapped with deeply $(\sim 100 \mathrm{~m})$ deployed RP's, as Queen Triggerfish were trapped more often in shallow ( $30 \mathrm{~m})$ deployed LP's. The difference in LPUE between gear types was statistically significant (Kruskal-Wallis H $=14.153,1 \mathrm{df}, \mathrm{p}<$ 0.001), which meant that separate analyses were conducted for the two gear types.

\subsubsection{GLM analysis for the LP landings}

For the LP landings data, the final GLM for Queen Triggerfish included the effects of Number of Fishing Pots, Boat ID, and Year. The value of the estimated model parameters and associated p-values are given in Annex 1b. The estimated effect of each explanatory variable on the number of Queen Triggerfish landed per fishing trip (LPT) are shown in figure 11. LPT significantly increased with the number of lobster pots collected per fishing trip $(p<0.001)$. There are clear differences in landings per trip between boats, a common phenomenon in all fisheries. Moreover, the significant year effect indicated a stock that increased from 2012 to 2014 followed by a sharp decrease in 2015, a slow recovery up to 2017, and again a decrease in 2018 (see also Fig. 12).

In order to perform a formal statistical test for the existence of a temporal trend in the abundance of Queen trigger fish after the closure, A GLM model was also fitted using "Year" as a linear predictor. After model selection, this GLM included the effect of Year and Boat ID only. The parameter for the Year term was negative $(-0.152, p=0.02)$ which indicates a decline over 2013-2018. 

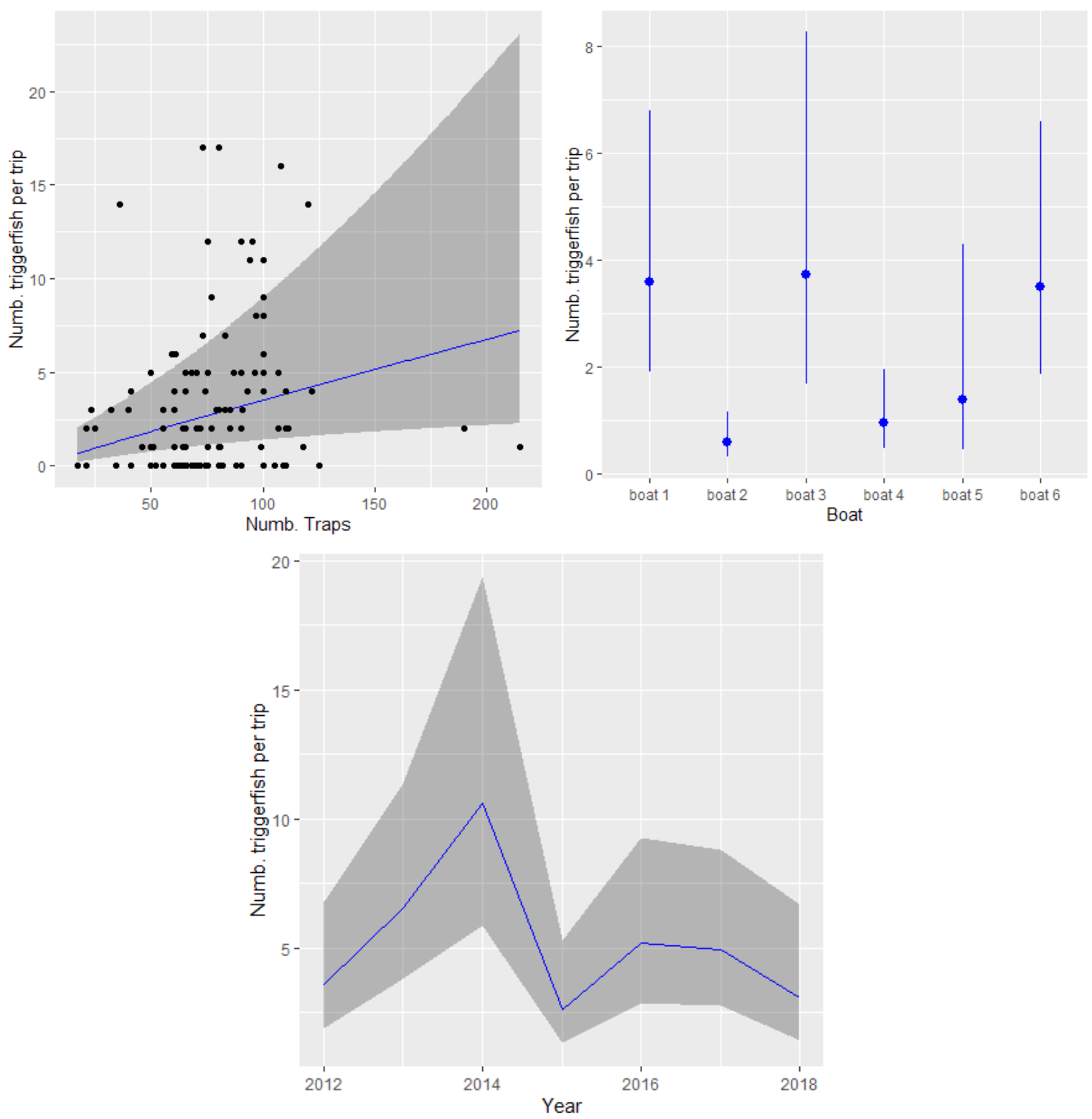

Figure 11. Estimated effects of Number of Fishing Pots, Boat ID and Year (with $90 \%$ confidence intervals) for the GLM model of the LP landings per trip of Queen Triggerfish. 


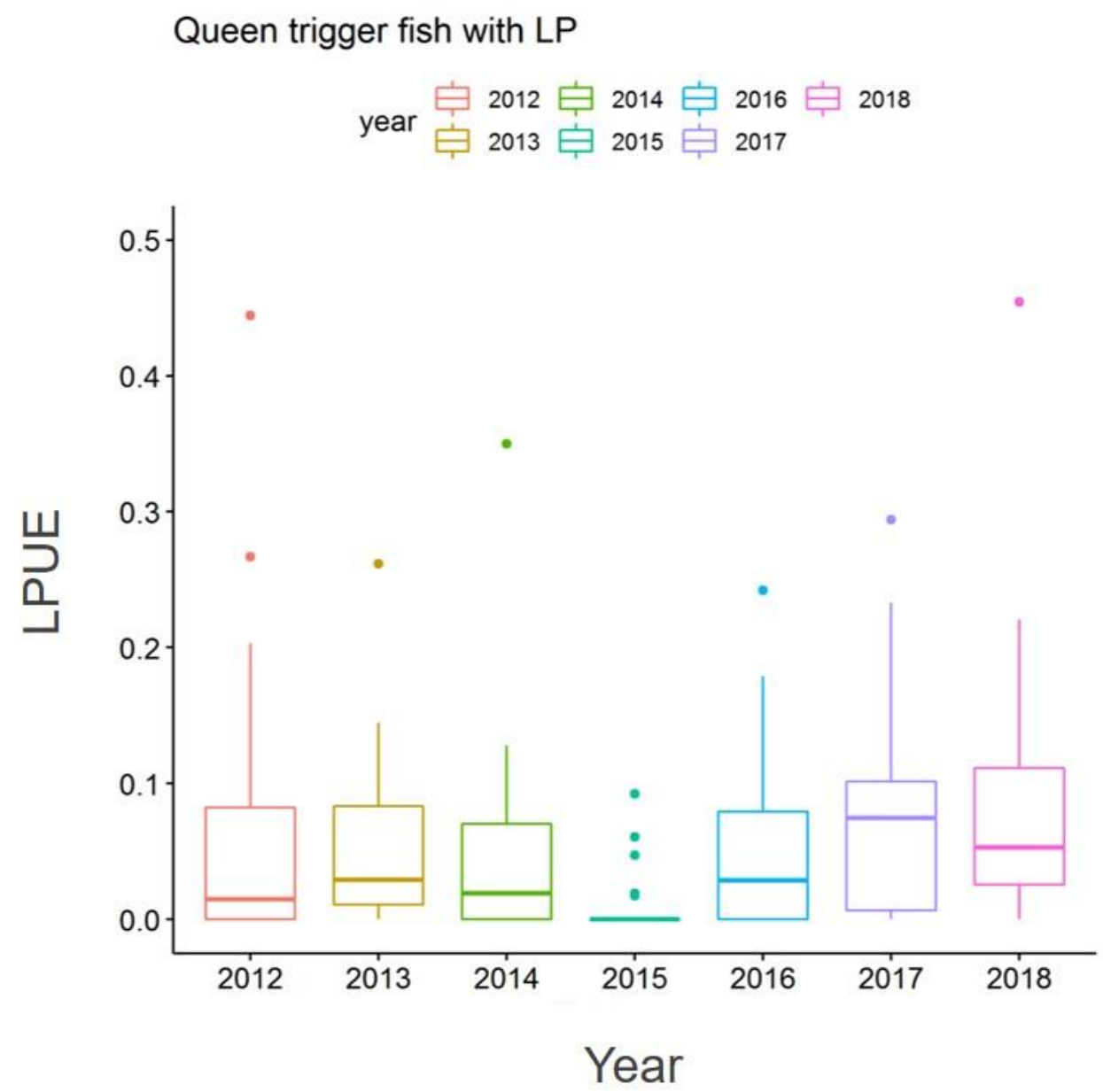

Figure 12. Box plot showing the number of Queen Triggerfish landed per lobster pot (LPUE) as a function of calendar year for the Saba Bank. Box plot shows interquartile range, median, maximum and minimum values, and outliers.

\subsubsection{GLM analysis for the RP landings}

For the RP catch data, none of the explanatory variables included in the model were found to be significant. Therefore, GLM plots for Queen Triggerfish from RP-landings are not provided. LPUE for Queen Triggerfish caught with redfish pots was relatively low (Fig. 13). 


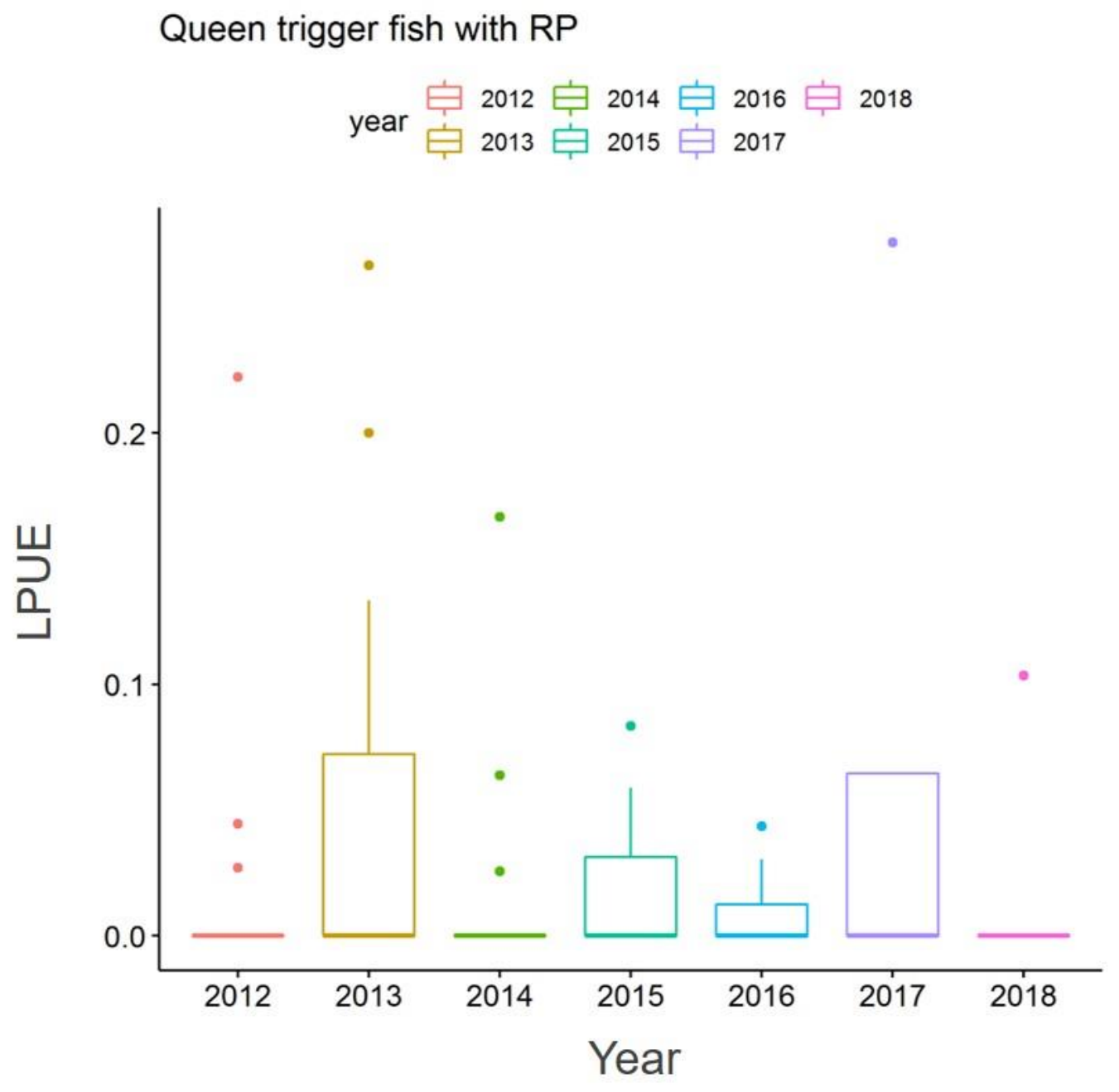

Figure 13. Boxplot showing the number of Queen Triggerfish landed per redfish pot (LPUE) as a function of calendar year for the Saba Bank. Box plot shows interquartile range, median, maximum and minimum values, and outliers.

\subsubsection{Length-frequency distributions}

We found no effect of gear type on mean fish length of landed Queen Triggerfish (Kruskal-Wallis $\mathrm{H}=$ $1.16,1 \mathrm{df}, \mathrm{p}=0.28)$. Hence, comparisons of size-frequencies were done by combining catch data of both gear types. Figure 14 shows the size frequency structure for all Queen Triggerfish recorded from the Saba Bank fishery combining both gear types. 


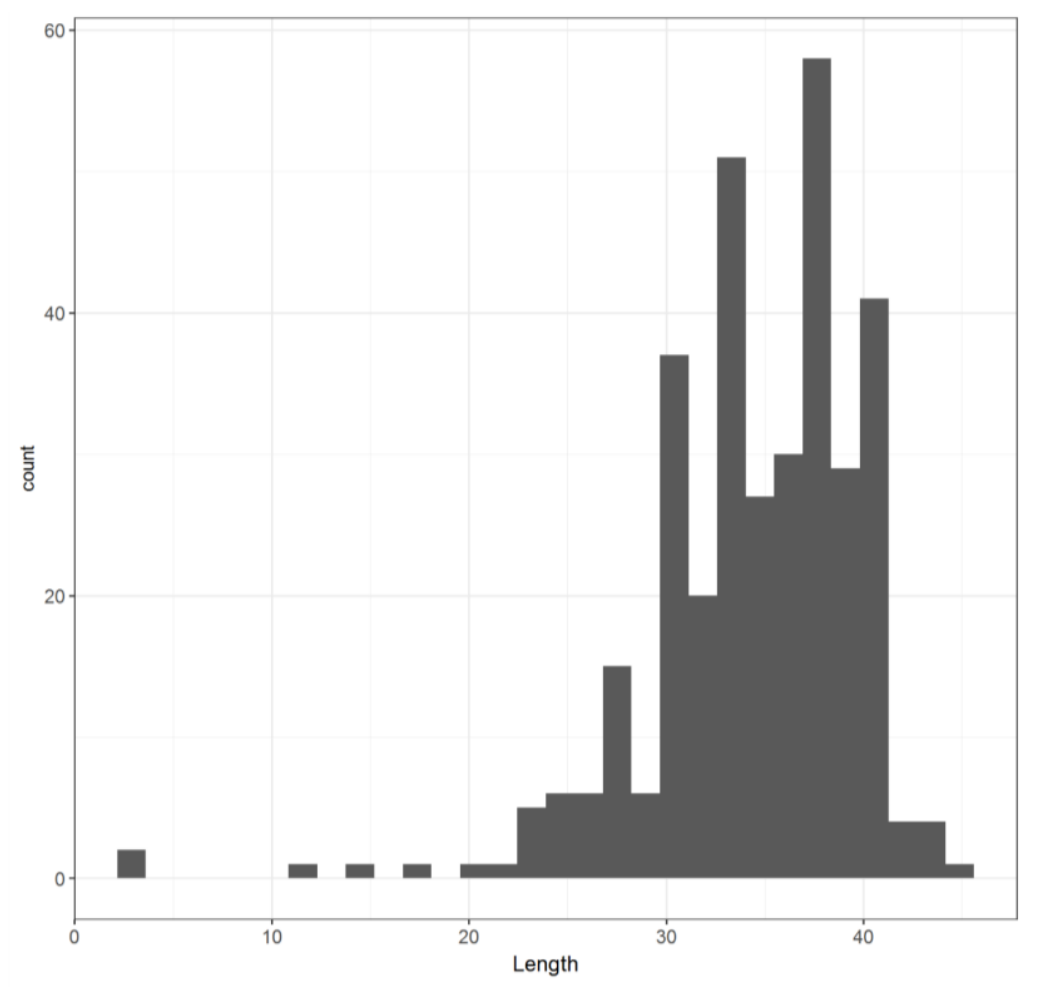

Figure 14. Frequency distribution of total length (TL) in cm for the Queen Triggerfish caught between 2012 and 2018, combining the data from both fishing gear types.

\subsubsection{Variation between years}

The mean total length (TL) of Queen Triggerfish caught in the Saba Bank lobster- and redfish pot fishery between the year 2012 and 2018 was $34.3 \mathrm{~cm}$. A small but statistically significant difference was found between years (Kruskal-Wallis $\mathrm{H}=13.428,6 \mathrm{df}=6, \mathrm{p}=0.037$ ). Pairwise comparison between years, showed that TL only differed between 2016 and 2017, with TL being smaller in 2016 compared to 2017 (Fig. 15). Hence, these results do not imply any significant trend over time.

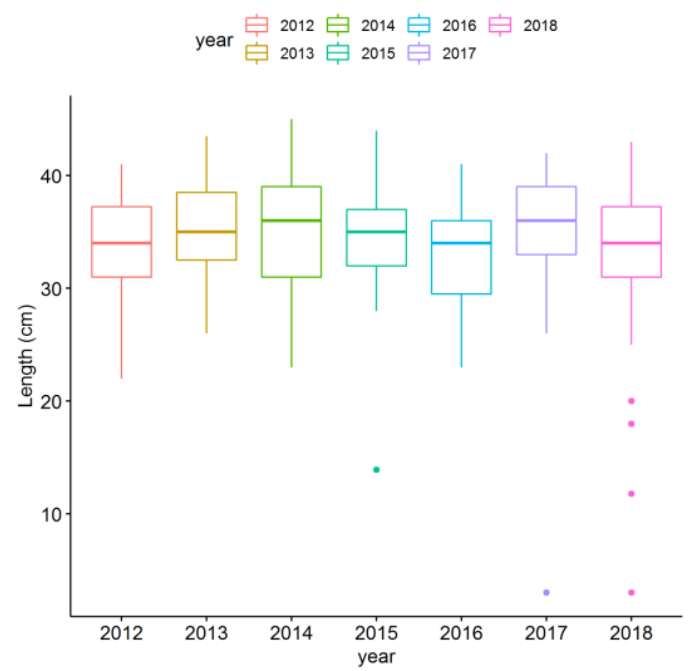

Figure 15. Mean total length (TL) of Queen Triggerfish per year for the Saba Bank (data from lobster- and redfish-pot fisheries pooled). Box plot shows interquartile range, median, maximum and minimum values, and outliers 


\subsubsection{Baseline population density and size-structure based on transect data}

Baseline population density estimates $( \pm$ SD) for Queen Triggerfish in coral reef habitat sites averaged $56.0 \pm 37.6$ (ind. ha-1) (Fig. 16). The mean size of Queen Triggerfish observed during diver fish-count transects was lower than $30 \mathrm{~cm}$, which is lower than the mean size of Queen Triggerfish reported in the landings (i.e. $34.3 \mathrm{~cm}$ ). Unfortunately, sample sizes were very limited, provided for only one shallow habitat and given only in $5-\mathrm{cm}$ size intervals. While these data are of value for long term monitoring purposes when identical monitoring methods are applied in the future, little can be said at this point other than that the fishes landed are roughly $5 \mathrm{~cm}$ in TL larger than the fishes found in the sampled in selected coral reef habitat.

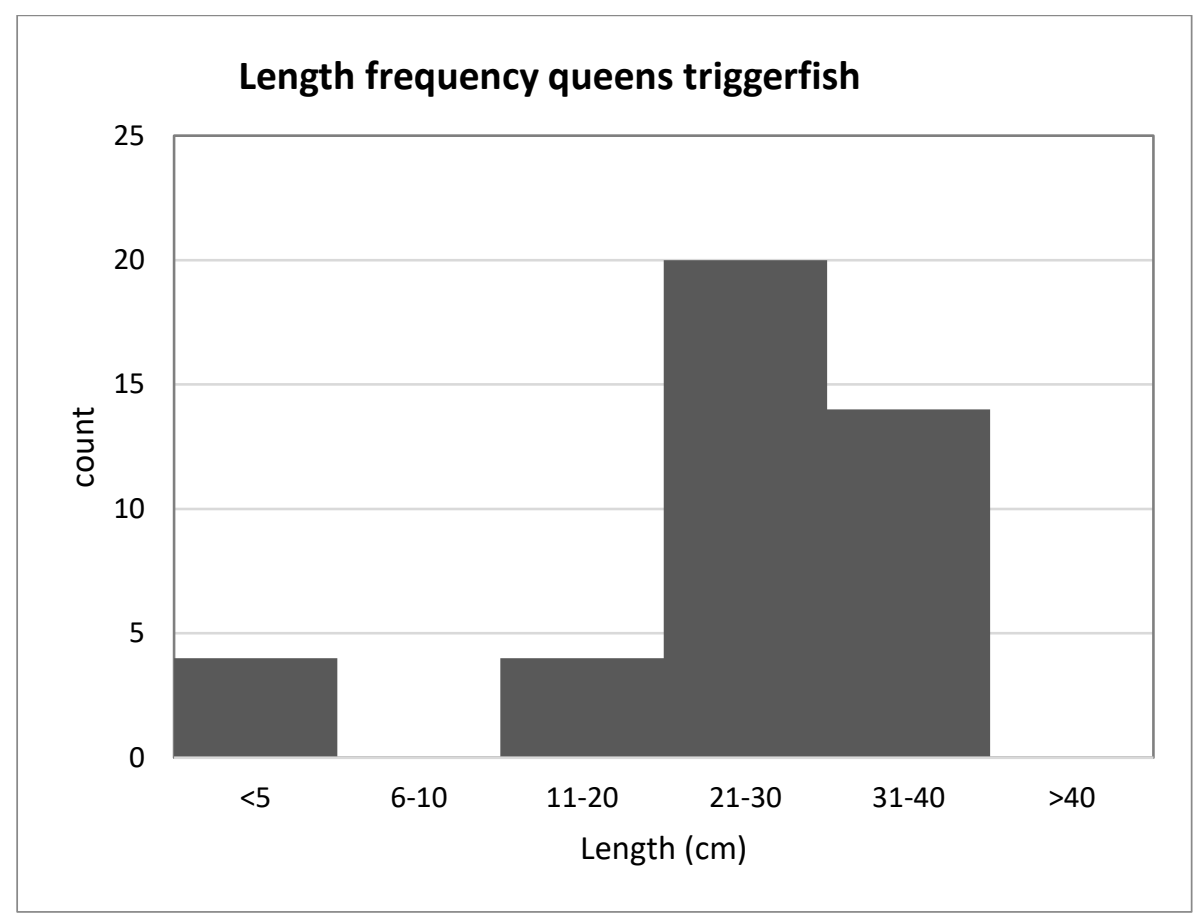

Figure 16. Frequency distribution of total length (TL) for the Queen Triggerfish observed during fish count transects in shallow coral reef habitat on the Saba Bank in 2011, 2013 and 2015. 


\section{Discussion}

Our results showed no detectable trend over the first five years of seasonal closure of the Moonfish Bank in either LPT or median size of Red Hind and Queen Triggerfish caught by vessels fishing on the Saba Bank. If anything, the size of Red Hind caught appears to have decreased significantly. Our main conclusion is that the quality of the port sampling data is poor, fisheries-independent data are too limited and the period over which to assess the effectiveness of the SPAG seasonal closure was too short to give a good assessment of the effectiveness of the closure. All of these issues likely contributed to the inconclusiveness of the current assessment.

Based on similar studies elsewhere (St. Thomas, St. Croix, Bermuda) it was expected that an effective seasonal spawning ground closure could have led to a significant increase over time in mean LPT and TL of the Red Hinds and Queen Triggerfish. For instance, in the case of comparable closures for St. Thomas and St. Croix, the mean TL of Red Hinds was monitored for 20 years, before and after the seasonal closure. Both locations showed a fluctuating increase and decrease in mean TL right after the closure for six years and then a steady increase for St. Thomas and a decrease for St. Croix (Nemeth 2006). A combination of poor enforcement and strategic fishing along the edges of the closures (Gell and Roberts 2003, Nemeth 2006) were suggested as likely causes for the failure of the Lang Bank SPAG at St. Croix to recover. Possibly the establishment of the Marine Conservation District (which permanently closed all fishing on St. Thomas) nine years after the seasonal closure, also had a substantial influence on the increase in mean TL of Red Hinds in St. Thomas. In our study, no such positive influence could be established for the first five years of SPAG seasonal closure for the Saba Bank. A big shortcoming in our case is the fact that aside from fisherman observations there is no numerically documented evidence of the exact spawning and aggregating season for this species on the Saba Bank. In the future, fisheries independent data is recommended to help establish the spawning season with greater certainty and precision.

While LPT is generally indicative of population density, and hence population health, its response to the seasonal SPAG closure is more difficult to predict than the response in size caught. On the longterm, protection of spawning output can be expected to positively influence recruitment to the population and hence ultimately lead to an increase in observed LPT. But this is only for a closed population. For fish populations of the Bank it is not yet known how "closed" they are and which source population actually delivers larvae to replenish the Bank populations. In addition, LPT is quite sensitive to several complicating factors that were not accurately or fully documented by means of port sampling. These factors include exact depth and habitat in which the traps were deployed and deployment time of the traps, all of which are variable and/or not precisely known. In addition, seasonal differences in fish behaviour which can serve to make them either more or less vulnerable to entering traps could have played a role. So while on the long-term an increase in LPT might be hoped for, initially one might expect a decline in LPT, particularly in the months of active closure (if indeed the closure eliminated fishing from an area otherwise fished). Alternatively, we speculate that a reduced LPT during the seasonal closure could also be expected in the case fishes seasonally moved away from the lobster and redfish fishing area to concentrate in an area where they were not being fished. In light of the shortage and imprecision of the data available from port sampling, a convincing detection of seasonal differences in LPT in these first five years was not possible.

Several studies have confirmed that the mean size of Red Hinds increases with depth (Olsen \& LaPlace 1978; Shapiro et al. 1993). Accordingly, in our results we found that Red Hinds caught in more shallow deployed lobster pots were on an average $2.0 \mathrm{~cm}$ shorter than the ones caught in the deeperset redfish pots (mean deployment depth of LP is $29 \mathrm{~m}$ versus $99 \mathrm{~m}$ for RP). In Puerto Rico it was found that Red Hind females, which tend to be smaller than the males, also migrate to shallower inshore areas while the males prefer to stay on the deeper offshore reefs (Colin et al. 1987). This may also explain our results. 
In St. Thomas, Red Hinds caught in December were consistently bigger, than Red Hinds caught in the other months of the year, whether or not this was a primary spawning month. It was suggested that this result was due to male Red Hinds arriving early at the St. Thomas spawning site than smaller female Red Hinds (Nemeth 2005). Then seasonal protection that starts when these first fish arrive, is needed to ensure the presence of sufficient male fish on grouper spawning grounds.

Based on LPT and crude number of catches it appears that most Red Hinds are caught in the sectors B4 and B5 of the Saba Bank (Fig. 2). Most Red Hinds caught in B5 were caught in February, the month that spawning is believed to end. The seasonally closed area also lies in sector B5 and the fisherman could have been fishing at the borders of the closed area, like seen in St. Croix (Nemeth 2005). There is one occasion that supports this: during a patrol of the coast guard in January in 2018, two Saban fishing vessels were seen handline-fishing in and on the border of the closed area (pers. comm. A. Kuramae Izioka, 2018). Red Hinds likely move around hundreds of meters while on the spawning grounds Strategic fishing along the borders of any closed area can cause an increase in catches and interfere with the purpose of the closure. Therefore, the closed area needs to be large enough to enclose most or all of the SPAG. However, the exact surficial extent of the Moonfish SPAGs for both the Red Hind and the Queen Triggerfish remain unknown. The size of SPAG for the Queen Triggerfish may be totally different than for the Red Hind as this species spawns in benthic nests and not freely in the water column.

It is also known that Red Hinds, while departing to their home sites, follow the relatively narrow coral reef ridges probably as a shelter from predation (Nemeth 2005). Therefore, it could be valuable to find out how the Red Hinds depart the SPAG on the Saba Bank and to incorporate these paths in the protected area.

It is likely that there are other SPAG sites on the Bank in addition to the Moonfish Bank site. For instance, in February 2015 a single fishing vessel caught 313 Red Hinds in one day with 12 traps and a single hand line. This suggests that this vessel may have been fishing at a SPAG site (Nemeth 2006). The fisherman concerned spoke about another SPAG in February in B5 (pers. comm., 2018). It is highly recommended to determine the possibility of other spawning sites on the Saba Bank, not only for the red Hind but also other species like the Queen Triggerfish and any other large species of commercial interest. For a good protection of the Red Hinds it is important to include all the SPAG sites on the Saba Bank in a fishing prohibition. Without knowing all sites, a full, Bank-wide seasonal closure for taking and landing Red Hinds might be preferable. This way all take of Red Hind during the spawning season could be prevented and could also greatly facilitate enforcement. A full seasonal closure on Red Hind fishery will not have a big negative economic effect on the fishery since the Red Hind is not a target species (those being redfish and lobster). 


\section{Conclusions and recommendations}

\subsection{Conclusions}

Our data over these first five years of the instituted legal Moonfish Bank SPAG seasonal fishing closure indicate no significant patterns of change in LPT or any expected increase in mean size landed for either Red Hind or Queen Triggerfish. This means that no significant positive effect of the closure on populations of Red Hind and Queen Triggerfish can yet be demonstrated. We propose several explanations for these results:

a) port monitoring data was too little and its quality was too poor to detect trends in size structure and LPT;

b) more time may be needed to be able to observe positive population-level feedback between spawning protection and the resulting fisheries catches;

c) proper enforcement of and abidance to the measure was lacking;

d) the closure was too small and only partially protected one of the several spawning populations,

e) the closed season was established just on time, before the developing SPAG fishery got a chance to greatly reduce fish size and density on the Bank

f) current fishing effort is so low that it cannot sort an effect on the populations of these species and hence a closure will have no measurable effect and finally;

g) current fishing effort can sort a negative impact on the populations of these species but the population status of both species was already healthy prior to the implementation of the closure such that the effect of closure was not measurable.

The current status of the two target species in the shallow coral reef zone of the Saba Bank is as follows: Red Hinds averaged $118.7 \pm 53.5$ (ind.ha ${ }^{-1}$ ) with a mean size of $\sim 24 \mathrm{~cm}$, while Queen Triggerfish averaged $56.0 \pm 37.6$ (ind. ha $^{-1}$ ) with a mean size of $\sim 29 \mathrm{~cm}$ (data from the years 2011, 2013 and 2015 pooled). For both species, the mean size landed in the fishery was considerably larger than the mean size of the population on the reef (Table 2). We cautiously suggest that compared to many other areas in the Caribbean (such as certainly Bonaire and Curaçao; Table 2) the populations of both the Red Hind and the Queen Triggerfish of the bank seem still comparatively healthy in terms of both population density and size-structure. 
Table 2. Indicators of stock status of Red Hind and Queen Triggerfish populations in the central Western Atlantic.

\begin{tabular}{|c|c|c|c|c|c|c|c|}
\hline Species & Area & $\begin{array}{l}\text { Mean size } \\
\text { in catch } \\
(\mathrm{cm})\end{array}$ & $\begin{array}{l}\text { CPUE fishery } \\
\text { (\#/trap } \\
\text { landed) }\end{array}$ & $\begin{array}{l}\text { Mean size in } \\
\text { population } \\
(\mathrm{cm})\end{array}$ & $\begin{array}{l}\text { Mean } \\
\text { population } \\
\text { density (\#/ ha) }\end{array}$ & Relative Status & Data source \\
\hline \multirow[t]{7}{*}{ Red Hind } & Saba Bank & 32 & $0.14^{*}$ & 24 & 119 & Healthy & This study \\
\hline & Bermuda & - & - & $48 * *$ & - & Recovered & $\begin{array}{l}\text { Luckhust and } \\
\text { Trott } 2009\end{array}$ \\
\hline & St. Croix & 38 & - & - & - & Recovered & $\begin{array}{l}\text { Nemeth et al. } \\
2006\end{array}$ \\
\hline & St. Thomas & 39 & - & - & - & Recovered & $\begin{array}{l}\text { Nemeth et al. } \\
2006\end{array}$ \\
\hline & St. Eustatius & 32 & - & - & - & Overfished & $\begin{array}{l}\text { De Graaf et al. } \\
2015\end{array}$ \\
\hline & Curacao & - & 0 & - & 0 & Decimated & $\begin{array}{l}\text { Debrot \& Criens } \\
\text { 2005, Vermeij et } \\
\text { al. } 2019\end{array}$ \\
\hline & Bonaire & - & 0 & - & 0 & Decimated & $\begin{array}{l}\text { Debrot \& Criens } \\
2005\end{array}$ \\
\hline \multicolumn{8}{|l|}{$\begin{array}{l}\text { Queen } \\
\text { Triggerfish }\end{array}$} \\
\hline & Saba Bank & 34 & $0.13^{*}$ & 29 & 56 & Healthy & This study \\
\hline & Pedro Bank & - & $2.9 * * *$ & - & - & Virgin (1970s) & Aiken 1975 \\
\hline & St. Croix & 29 & - & - & - & Recovering & $\begin{array}{l}\text { Hernandez et al. } \\
2019\end{array}$ \\
\hline & Puerto Rico & 29 & - & - & - & Recovering & $\begin{array}{l}\text { Hernandez et al. } \\
2019\end{array}$ \\
\hline & USVI & - & - & - & - & Declining & McCarthy 2012 \\
\hline & Central Brazil & - & - & - & - & Fully exploited? & $\begin{array}{l}\text { de Albuquerque } \\
\text { et al. } 2011\end{array}$ \\
\hline & Florida & - & 0 & - & 0 & Decimated & $\begin{array}{l}\text { Kellison et al. } \\
2012\end{array}$ \\
\hline & St. Eustatius & 39 & 0 & - & 0 & Decimated & $\begin{array}{l}\text { De Graaf et al. } \\
2015\end{array}$ \\
\hline & Curacao & - & 0 & - & 0 & Decimated & $\begin{array}{l}\text { Debrot \& Criens } \\
\text { 2005, Vermeij et } \\
\text { al. } 2019\end{array}$ \\
\hline & Bonaire & - & 0 & - & 0 & Decimated & $\begin{array}{l}\text { Debrot \& Criens } \\
2005\end{array}$ \\
\hline \multicolumn{8}{|c|}{ - : no data available; ${ }^{*}$ : catches based on $29-\mathrm{m}$-deep lobster pots; ${ }^{* *}$ : on the spawning grounds } \\
\hline$* * *$ : short & soak time. & & & & & & \\
\hline
\end{tabular}

\subsection{Management recommendations}

Based on experiences elsewhere in the Caribbean, it can be seen that intensified fisheries on spawning aggregations have, without exception, led to the collapse of the stocks involved. There are several possible management options with which to protect SPAG's. These include:

- $\quad$ Area closure, both permanent or temporary/seasonal

- $\quad$ Full seasonal closure, prohibiting all catches and not just catches from inside the closure area.

- Annual quota management 
- $\quad$ Size limits

- $\quad$ Gear restrictions

- $\quad$ Access permits (Rhodes \& Warren-Rhodes 2005).

Permanent or seasonal closures for fishing at a SPAG have been suggested to offer the best protection for fish populations (Sadovy de Mitcheson \& Erisman 2012) and are currently used on several SPAG's throughout the Caribbean (Rhodes \& Warren-Rhodes 2005). Protecting spawning aggregations is a basic need for sustainable management and fishery production. Therefore, our main management recommendation is that the closure should be continued. At the same time, based on the results presented in this study, there seems no evidence yet to suggest that the closure had a positive effect on the populations of Red Hind and Queen Triggerfish, which would warrant the closure to be expanded in time or in space at this time. Further research is needed in order to assess current closure functioning and the possible need for further measures.

\subsection{Research recommendations}

\subsubsection{Fisheries port sampling}

The port sampling data collected up to this point remain inconclusive. Nevertheless, fisheries port sampling data is essential and must continue, but in a slightly different way to yield better and more consistent data. For example, data collection can be conducted in a more consistent manner so that less data needs to be removed from analysis. Also, sample sizes were highly variable and often small. This greatly reduces the likelihood of demonstrating trends in LPT or fish length frequencies over time. We recommend that significantly more fish should be measured during port sampling. Ideally sex and maturity data should also be collected on the landed fish so as to yield information on sex ratios of the catch. Healthy sex ratios at the time of spawning are close to 1:4 (M:F, Beets and Friedlander 1999; Nemeth 2005). Fisheries focus on larger fish, which are more often males, and causes sex ratios to become skewed towards females (Colin et al. 1987; Beets and Friedlander 1999). Sex ratios are a variable affected by fishing and can serve as an indicator of the effects of fishing on the population. In conclusion, a bigger and more consistent sample size could considerably help to make more reliable inferences and the addition of information on the sex and maturity of the fishes landed would be very helpful as an additional indicator of population reproductive health and reproductive seasonality.

\subsubsection{Fisheries-independent SPAG survey}

To provide more-definitive answers and clarify the need for and functioning of closures in protecting Red Hind and Queen Trigger Fish during their annual mass spawning events, it will be necessary to conduct an additional fishery-independent assessment. In specific, this should be done to provide further information on:

- $\quad$ the exact seasonality of the spawning events

- the surficial extent of the spawning aggregation(s)

- $\quad$ the locations of additional spawning aggregations on the Bank

- the total number and size-frequency of the fishes participating in the spawning events

- the overall status (densities and size-frequency distributions) of both species in the different habitats of the Bank.

In the course of a conch survey for the Bank, 131 video transects were made across much of the Bank (de Graaf et al. 2017) using the method developed by Boman et al. (2016). These video transects could be analyzed to examine patterns of abundance of both target species in the various habitats. As the video transects did not use double cameras, exact size estimation for fishes will not be possible but for a subset of fish photographed at good angles, even relatively good size estimation should be possible. 


\section{Acknowledgments}

This research was financed by the Ministry of Agriculture Nature and Food Quality (LNV) as part of their "BO" policy support research program with Wageningen University and Research under the project BO-43-021-04-002 and project number 4318100256. We are especially grateful to Hayo Haanstra, Gelare Nader, Paul Hoetjes, and Yoeri de Vries for their support. Special thanks are due to Kai Wulf, the Saba Conservation Foundation crew and volunteers, and the Saba Bank Management Unit that generously provided facilities and logistical assistance in all aspects of the fieldwork and the Saba fishermen for their cooperation. Erik Meesters and Tatiana Becker is thanked for their roles in making available the part data on which this report is based. Finally, we are very grateful to Paul Hoetjes and Matthijs van der Geest for their valuable reviews and Jan Tjalling van der Wal for making Fig. 3. 


\section{Quality Assurance}

Wageningen Marine Research utilises an ISO 9001:2015 certified quality management system. This certificate is valid until 15 December 2021. The organisation has been certified since 27 February 2001. The certification was issued by DNV GL.

Furthermore, the chemical laboratory at IJmuiden has NEN-EN-ISO/IEC 17025:2005 accreditation for test laboratories with number L097. This accreditation is valid until $1^{\text {th }}$ of April 2021 and was first issued on 27 March 1997. Accreditation was granted by the Council for Accreditation. The chemical laboratory at IJmuiden has thus demonstrated its ability to provide valid results according a technically competent manner and to work according to the ISO 17025 standard. The scope (L097) of de accredited analytical methods can be found at the website of the Council for Accreditation (www.rva.nl).

On the basis of this accreditation, the quality characteristic $Q$ is awarded to the results of those components which are incorporated in the scope, provided they comply with all quality requirements. The quality characteristic $\mathrm{Q}$ is stated in the tables with the results. If, the quality characteristic $\mathrm{Q}$ is not mentioned, the reason why is explained.

The quality of the test methods is ensured in various ways. The accuracy of the analysis is regularly assessed by participation in inter-laboratory performance studies including those organized by QUASIMEME. If no inter-laboratory study is available, a second-level control is performed. In addition, a first-level control is performed for each series of measurements.

In addition to the line controls the following general quality controls are carried out:

- Blank research.

- Recovery.

- Internal standard

- Injection standard.

- Sensitivity.

The above controls are described in Wageningen Marine Research working instruction ISW 2.10.2.105. If desired, information regarding the performance characteristics of the analytical methods is available at the chemical laboratory at IJmuiden.

If the quality cannot be guaranteed, appropriate measures are taken. 


\section{References}

Aiken, K.A. 1975. The Biology, Ecology and Bionomics of the Triggerfishes, Balistidae. In: J.L. Munro (ed.), Caribbean Coral Reef Fishery Resources. A second edition of 'The Biology, Ecology, Exploitation and Management of Caribbean Reef Fishes: Scientific Report of the ODA/UWI Fisheries Ecology Research Project 1969-1973: University of the West Indies, Jamaica, pp. 191-205. International Center for Living Aquatic Resources Management, Makati, Metro Manila.

Albuquerque, C. Q. de, Martins, A. S., de Oliveira Leite, N., de Araújo, J. N. and Ribeiro, A. M. 2011. Age and growth of the Queen Triggerfish Balistes vetula (Tetraodontiformes, Balistidae) of the central coast of Brazil. Brazilian J. Oceanogr., 59(3):231-239.

Beek, I.J.M. van and H.G.W Meesters. 2013. Saba Bank research expedition 2011. - Progress report. Wageningen University \& Research Report C018/13. Wageningen Marine Research (University \& Research centre), Wageningen, The Netherlands, $46 \mathrm{p}$.

Beek, I.J.M. van, and H.G.W Meesters. 2014. Saba Bank research expedition 2013. - Progress report. Wageningen University \& Research Report C018/13. Wageningen Marine Research (University \& Research centre), Wageningen, The Netherlands, $45 \mathrm{p}$.

Beets, J. \& Friedlander, A. (1999). Evaluation of conservation strategy: a spawning aggregation closure for red hind, Epinephelus guttatus, in the U.S. Virgin Islands. Environmental Biology of Fishes 55: 91-98 p.

Boman, E. M., De Graaf, M., Nagelkerke, L. A., Van Rijn, J., Zu Schlochtern, M. M., \& Smaal, A. (2016). Underwater towed video: a novel method to estimate densities of queen conch (Lobatus gigas; Strombidae) across its depth range. Journal of shellfish research 35(2): 493-499.

Brose, U., Pavao-Zuckerman, M., Eklöf, A., Bengtsson, J., Berg, M. P., Cousins, S. H., Mulder, C., Verhoef, H. A. \& Wolters, V. (2005). Spatial Aspects of Food Webs. In: De Ruiter, P. C., Wolters, V. \& Moore, J. C. (Eds.) Dynamic Food Webs. Elsevier, London: 463-469 p.

Brule, T. 2018. Epinephelus guttatus. The IUCN Red List of Threatened Species 2018: e.T132770A46917106. http://dx.doi.org/10.2305/IUCN.UK.2018-

2.RLTS.T132770A46917106.en. Downloaded on 14 June 2019.

Brunel. T, Kuramae, A. Odinga, J. Debrot, A. O. Update on the 2016-2017 catch trends in the Saba Bank fisheries. Wageningen marine research, Wageningen marine research report C083/18. 22 pp.

Caribbean Fisheries Management Council (CFMC) 2005. Comprehensive amendment to the fisheries management plans (FMPs) of the U.S. Caribbean to address required provisions of the MagnusonStevens Fishery Conservation and Management Act. CFMC, San Juan, Puerto Rico. 624 pp.

Chiappone, M., Sluka, R., \& Sullivan Sealey, K. (2000). Groupers (Pisces: Serranidae) in fished and protected areas of the Florida Keys, Bahamas and northern Caribbean. Marine Ecology Progress Series 198: 261-272 p.

Colin, P. L., Shapiro, D. Y. \& Weiler, D. (1987). Aspects of the reproduction of two groupers, Epinephelus guttatus and E. striatus in the West Indies. Bulletin of Marine Science 40 (2): 220$230 \mathrm{p}$.

Cornish, A. \& Eklund, A. M. (2003). Epinephelus striatus. The IUCN Red List of Threatened Species 2003: e.T7862A12858266.

Cushion, N., Constantine, S., Semon, K., \& Sullivan-Sealey, K. (2007). Assessment of island and habitat-specific reef fish assemblages in the Bahamas using fisheries-independent data. Proc. GCFI 59: 435-443.

Damen, I. van (2018). Student handbook for Saba Bank fisheries and monitoring. Bsc internship report. HAS Hogeschool, s-Hertogenbosch, The Netherlands, $31 \mathrm{p}$.

DCNA (2013). Red hind spawning site closed. http://www.dcnanature.org/ Accessed 10th of July, 2018.

DCNA (2018). Saba Bank National Park. http://www.dcnanature.org/ Accessed 29th of March, 2018.

Debrot, A. O., S. R. Criens 2005. Reef fish stock collapse documented in Curaçao, Netherlands Antilles, based on a preliminary comparison of recreational spear fishing catches half a century apart. 32nd AMLC (Abstract) 
Debrot, A. O. and I. Nagelkerken. 2006. Recovery of the long-spined sea urchin Diadema antillarum in Curaçao (Netherlands Antilles) linked to lagoonal and wave-sheltered shallow rocky habitats. Bull. Mar. Sci. 79(2): 415-424.

Dilrosun, F. (2000). Monitoring the Saba Bank fisheries. Departemental report, Department of Public Health and Environmental Hygiene, Environmental Division, Willemstad, Curacao, 57 p.

Gell, F. R. \& Roberts, C. M. (2003). Benefits beyond boundaries: the fishery effects of marine reserves. Trends in Ecology and Evolution 18: 448-455 p.

Gladstone, W. (1994). Lek-like spawning, parental care and mating periodicity of the triggerfish Pseudobalistes flavimarginatus (Balistidae). Environmental Biology of Fishes, 39(3): 249-257.

(GMFMC) Gulf of Mexico Fishery Management Council. 2017. Gray Triggerfish Rebuilding Plan: Final Amendment 46 to the Fishery Management Plan for the Reef Fish Resources of the Gulf of Mexico Including Environmental Assessment, Fishery Impact Statement, Regulatory Impact Review, and Regulatory Flexibility Act Analysis. NOAA \& GMFMC, 200 pp.

Graaf, J. de, Brunel, T. P. A., Nagelkerke, L. A. J. \& Debrot, A. O. (2017). Status and trends Saba Bank fisheries. Wageningen University \& Research Report C077/17. Wageningen Marine Research (University \& Research centre), Wageningen, The Netherlands, $124 \mathrm{p}$.

Hernandez, J. M. R., Pena Alvarado, N., Velez, K. C., Nemeth, R., Appeldoorn, R., \& Shervette, V. (2019). Queen Triggerfish Reproductive Biology in US Caribbean Waters. TRANSACTIONS OF THE AMERICAN FISHERIES SOCIETY, 148(1): 134-147.

Jackson, J. B. C., Kirby, M. X., Berger, W. H., Bjorndal, K. A., Botsford, L. W., Bourque, B. J., Bradbury, R. H., Cooke, R., Erlandson, J., Estes, J. A., Hughes, T. P., Kidwell, S., Lange, C. B., Lenihan, H. S., Pandolfi, J. M., Peterson, C. H., Steneck, R. S., Tegner, M. J. \& Warner, R. R. (2001). Historical Overfishing and the Recent Collapse of Coastal Ecosystems. Science 293: 629$638 \mathrm{p}$.

Jarvis, E. T., Allen, M. J., \& Smith, R. W. (2004). Comparison of recreational fish catch trends to environment-species relationships and fishery-independent data in the southern California bight, 1980-2000. CALIFORNIA COOPERATIVE OCEANIC FISHERIES INVESTIGATIONS REPORT, 45, 167.

Kadison, E., Nemeth, R. S. \& Blondeau, J. E. (2009). Assessment of an unprotected red hind (Epinephelus guttatus) spawning aggregation on Saba Bank in the Netherlands Antilles. Bulletin of Marine Science 85 (1): 101-118 p.

Kellison, G.T., McDonough, V., Harper, D.E. and Tilmant, J.T. 2012. Coral reef fish assemblage shifts and declines in Biscayne National Park, FLORIDA, USA. Bulletin of Marine Science 88(1): 147-182.

Land, J. van der (1977). The Saba Bank - a large atoll in the Northeastern Caribbean, FAO Fisheries Report no. 200, Rijksmuseum van Natuurlijke Historie, Leiden, The Netherlands, 469-481 p.

Linardich, C., Ralph, G., Carpenter, K., Cox, N., Robertson, D.R., Harwell, H., Acero P., A., Anderson Jr., W., Barthelat, F., Bouchereau, J. J., Brown, J., Buchanan, J., Buddo, D., Collette, B., ComerosRaynal, M., Craig, M., Curtis, M., Defex, T., Dooley, J., Driggers III, W., Elfes Livsey, C., Fraser, T., Gilmore Jr., R., Grijalba Bendec, L., Hines, A., Kishore, R., Lindeman, K., Maréchal, J.-P., McEachran, J., McManus, R., Moore, J., Munroe, T., Oxenford, H., Pezold, F., Pina Amargós, F., Polanco Fernandez, A., Polidoro, B., Pollock, C., Robins, R., Russell, B., Sayer, C., Singh-Renton, S., Smith-Vaniz, W., Tornabene, L., Van Tassell, J., Vié, J.-C. \& Williams, J.T. (2017). The conservation status of marine bony shorefishes of the Greater Caribbean. IUCN, Gland, Switzerland, $75 \mathrm{p}$.

Liu, J., Zapfe, G., Shao, K.-T., Leis, J.L., Matsuura, K., Hardy, G., Liu, M. \& Tyler, J. 2015. Balistes vetula (errata version published in 2016). The IUCN Red List of Threatened Species 2015: e.T2539A97664057. Downloaded on 27 March 2019.

Luckhurst, B. E., Barnes, J. A., \& Sadovy, Y. (1992). Record of an unusually large red hind, Epinephelus guttatus (Pisces: Serranidae) from Bermuda with comments of its age. Bulletin of Marine Science 51 (2): 267-270 p.

Luckhurst, B.E. and Trott, T.M. (2009) Seasonally-closed spawning aggregation sites for Red Hind (Epinephelus guttatus): Bermuda's experience over 30 years (1974-2003). Proceedings of the Gulf and Caribbean Fisheries Institute 61: 331-336.

Manooch III, C.S., and Drennon, C.L., 1987. Age and growth of yellowtail snapper and queen triggerfish collected from the U.S. Virgin Islands and Puerto Rico. Fish. Res., 6: 53-68.

McCarthy, K. 2012. Commercial fishery landings of queen triggerfish and blue tang in the United States Caribbean, 1983-2011. SEDAR30-AW-04. National Marine Fisheries Service, Southeast Fisheries Science Center. 17 pp. 
Meesters, E. H., Nijkamp, H. \& Bijvoet, L. (1996). Towards sustainable management of the Saba Bank, a report for the Department of Public Health and Environment (VOMIL) Curacao, Netherlands Antilles. AIDEnvironment, Amsterdam, The Netherlands, $51 \mathrm{p}$.

Menezes, M. F. 1979. Aspectos da biologia e biometria do cangulo, Balistes vetula Linnaeus, no Nordeste do Brasil. Arq. Ciên. Mar.Bras. 19: 57-68.

Monge, A.M. 2012. Testing sustainability in Triggerfish and Leopard grouper in the Northern Gulf of California. Capstone papers, UC San Diego. 25 p.

Munro, J. L. \& Blok, L. (2005). The Status of Stocks of Groupers and Hinds in the Northeastern Caribbean. 56th Gulf and Caribbean Fisheries Institute 56: 283-294 p.

Nemeth, R. S. (2009). Dynamics of reef fish and decapod crustacean spawning aggregations. In: Nagelkeren, I. (Ed.) Ecological Connectivity among Tropical Coastal Ecosystems. Springer, Dordrecht, The Netherlands: 73-134 p.

Nemeth, R. S., Kadison, E., \& Blondeau, J. (2006). Comparative Investigations of Red Hind (Epinephelus guttatus) spawning aggregations under different management strategies; fully protected Marine Reserves in the United States Virgin Islands and an unmanaged fishery on the Saba Bank in the Netherlands Antilles, final report NOAA Grant \#NA03NMF 4630329. Center for Marine and Environmental Studies, University of Virgin Islands, St. Thomas, 25 p.

Nemeth, R.S. (2005). Population characteristics of a recovering US Virgin Islands red hind spawning aggregation following protection. Marine Ecology Prog Ser 286: 81-97 p.

Olsen DA, LaPlace JA (1978) A study of Virgin Islands Grouper Fishery based on a Breeding Aggregation. In: Proceedings of the Gulf and Caribbean Fisheries Institute, 31: 130-144 p.

Potts, J. C., \& Manooch, C. S. (1995). Age and growth of red hind and rock hind collected from North Carolina through the dry Tortugas, Florida. Bulletin of Marine Science 56 (3): 784-794 p.

R Core Team. (2017). R: A language and environment for statistical computing

Rhodes, K. L., \& Warren-Rhodes, K. (2005). Management Options for Fish Spawning Aggregations of Tropical Reef Fishes: A Perspective. Report prepared for the Pacific Island Countries Coastal Marine Program, The Nature Conservancy, South Brisbane, Australia, 55 p.

Sadovy de Mitcheson, Y. (2016). Mainstreaming Fish Spawning Aggregations into Fishery Management Calls for a Precautionary Approach. BioScience 66 (4): 295-306 p.

Sadovy de Mitcheson, Y., Cornish, A., Domeier, M., Colin, P. L., Russell, M., \& Lindeman, K. C. (2008). A global baseline for spawning aggregations of reef fishes. Conservation Biology 22(5): 1233-1244 p.

Sadovy de Mitcheson, Y., \& Erisman, B. (2012). Fishery and biological implications of fishing spawning aggregations, and the social and economic importance of aggregating fishes. In: Sadovy de Mitcheson, Y. \& Colin, P.L. (Eds.) Reef Fish Spawning Aggregations: Biology, Research and Management. Springer, Dordrecht, The Netherlands: 225-284 p.

Sadovy, Y., \& Figuerola, M. (1992). The status of Red Hind Fishery in Puerto Rico and St. Thomas as determined by Yield-per-recruit Analysis. Proceedings of 42nd Gulf and Caribbean Fishery Institute 42: $23-38 \mathrm{p}$.

Shapiro, D. Y., Sadovy, Y. \& McGehee, M.A. (1993). Size, Composition, and Spatial Structure of the Annual Spawning Aggregation of the Red Hind, Epinephelus guttatus (Pisces: Serranidae). Copeia Vol. 1993 (2): 399-406 p.

SRFA. (2017). Infographic: Protecting fish aggregations: Protecting our future. Science and conservation of fish aggregations., https://www.scrfa.org/, Accessed 29th of March, 2018.

Staatssectetaris van Economische Zaken, Dijksma S.A.M. (2013). Besluit van de Staatssecretaris van Economische Zaken van 27 november 2013, nr. DGA-DAD/13195817, houdende visverbod voor een bepaald tijdvak voor Saba. Staatscourant Nr. 33358, 27 november 2013.

Stamatopoulos C. 2002. Sample-based fishery surveys: a technical handbook. FAO Fisheries Technical Paper. No. 425. Rome, FAO. Pp. 132.

Toller, W., Debrot, A. O., Vermeij, M. J. A. \& Hoetjes, P. C. (2010). Reef fishes of Saba Bank, Netherlands Antilles: Assemblage structure across a Gradient of Habitat Types. PLoS ONE 5 (5): e9207.

Vermeij, M.J.A., Latijnhouwers, K.R.W., Dilrosun, F., Chamberland, V.F., Dubé, C.E., Van Buurt, G., Debrot, A.O. (n press) Historical changes (1905-present) in catch size and composition reflect altering fisheries practices on a small Caribbean island. PLoS 1. 


\section{Justification}

Report C040/20

Project Number: 4318100256

The scientific quality of this report has been peer reviewed by a colleague scientist and a member of the Management Team of Wageningen Marine Research

Approved: $\quad$ Dr. M. van der Geest

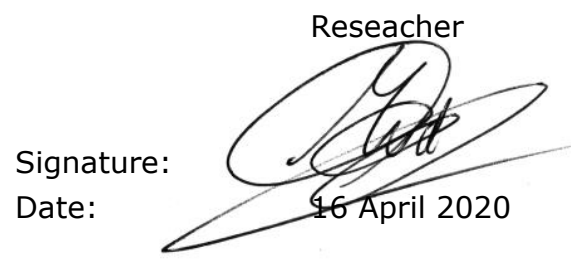

Approved: $\quad$ Drs. J. Asjes

Manager/

Signature:

Date:

16 April 2020 


\section{Annex 1 : Output of the final GML models only including significant terms}

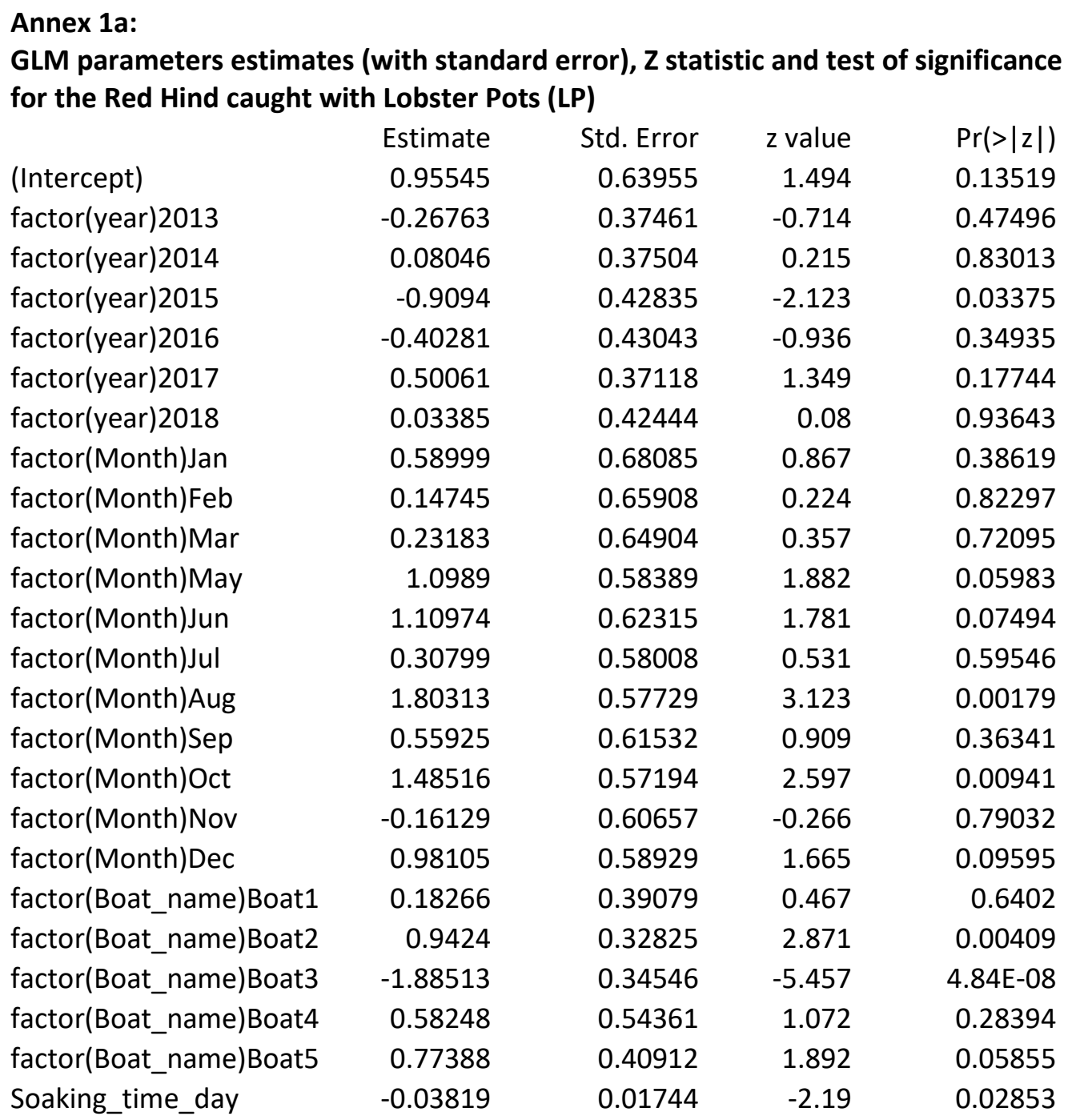




\section{Annex 1b:}

GLM parameters estimates (with standard error), Z statistic and test of significance for the Queen Triggerfish caught with Lobster Pots (LP)

$\begin{array}{lrrrr} & \text { Estimate } & \text { Std. Error } & z \text { value } & \operatorname{Pr}(>|z|) \\ \text { (Intercept) } & -2.79701 & 1.30339 & -2.146 & 0.031878 \\ \text { factor(year)2013 } & 0.59944 & 0.34257 & 1.75 & 0.080148 \\ \text { factor(year)2014 } & 1.08634 & 0.35984 & 3.019 & 0.002537 \\ \text { factor(year)2015 } & -0.3169 & 0.40221 & -0.788 & 0.430758 \\ \text { factor(year)2016 } & 0.36625 & 0.38378 & 0.954 & 0.339922 \\ \text { factor(year)2017 } & 0.31292 & 0.35498 & 0.882 & 0.378036 \\ \text { factor(year)2018 } & -0.15418 & 0.46111 & -0.334 & 0.738102 \\ \text { factor(Boat_name)Boat1 } & -1.30018 & 0.3937 & -3.302 & 0.000958 \\ \text { factor(Boat_name)Boat2 } & 0.02541 & 0.29268 & 0.087 & 0.930827 \\ \text { factor(Boat_name)Boat3 } & -1.78512 & 0.30832 & -5.79 & 7.04 \mathrm{E}-09 \\ \text { factor(Boat_name)Boat4 } & -0.93468 & 0.5616 & -1.664 & 0.096049 \\ \text { factor(Boat_name)Boat5 } & 0.06147 & 0.38671 & 0.159 & 0.873709 \\ \text { Log (nr. of pots/trip) } & 0.93682 & 0.28873 & 3.245 & 0.001176\end{array}$


Wageningen Marine Research

$\mathrm{T}+31(0) 317480900$

E: marine-research@wur.nl

www.wur.eu/marine-research

Visitors' address

- Ankerpark 271781 AG Den Helder

- Korringaweg 7, 4401 NT Yerseke

- Haringkade 1, 1976 CP IJmuiden
With knowledge, independent scientific research and advice, Wageningen Marine Research substantially contributes to more sustainable and more careful management, use and protection of natural riches in marine, coastal and freshwater areas.

Wageningen Marine Research is part of Wageningen University \& Research. Wageningen University \& Research is the collaboration between Wageningen University and the Wageningen Research Foundation and its mission is: 'To explore the potential for improving the quality of life' 